Atmos. Chem. Phys., 13, 7321-7341, 2013

www.atmos-chem-phys.net/13/7321/2013/

doi:10.5194/acp-13-7321-2013

(C) Author(s) 2013. CC Attribution 3.0 License.

\title{
Ozone photochemistry in boreal biomass burning plumes
}

\author{
M. Parrington ${ }^{1}$, P. I. Palmer ${ }^{1}$, A. C. Lewis ${ }^{2}$, J. D. Lee ${ }^{2}$, A. R. Rickard ${ }^{3,4}$, P. Di Carlo ${ }^{5,6}$, J. W. Taylor ${ }^{7}$, J. R. Hopkins ${ }^{2}$, \\ S. Punjabi ${ }^{8}$, D. E. Oram ${ }^{9}$, G. Forster ${ }^{9}$, E. Aruffo ${ }^{5,6}$, S. J. Moller ${ }^{2}$, S. J.-B. Bauguitte ${ }^{10}$, J. D. Allan ${ }^{7,11}$, H. Coe ${ }^{7}$, and \\ R. J. Leigh ${ }^{12}$ \\ ${ }^{1}$ School of GeoSciences, The University of Edinburgh, Edinburgh, UK \\ ${ }^{2}$ National Centre for Atmospheric Science, Department of Chemistry, University of York, York, UK \\ ${ }^{3}$ National Centre for Atmospheric Science, School of Chemistry, University of Leeds, Leeds, UK \\ ${ }^{4}$ now at the National Centre for Atmospheric Science, Department of Chemistry, University of York, York, UK \\ ${ }^{5}$ Center of Excellence CETEMPS, University of L'Aquila, L'Aquila, Italy \\ ${ }^{6}$ Department of Physical and Chemical Sciences, University of L'Aquila, L'Aquila, Italy \\ ${ }^{7}$ School of Earth, Atmospheric and Environmental Sciences, University of Manchester, Manchester, UK \\ ${ }^{8}$ Department of Chemistry, University of York, York, UK \\ ${ }^{9}$ National Centre for Atmospheric Science, School of Environmental Sciences, University of East Anglia, Norwich, UK \\ ${ }^{10}$ Facility for Airborne Atmospheric Measurements, Bedford, UK \\ ${ }^{11}$ National Centre for Atmospheric Science, University of Manchester, Manchester, UK \\ ${ }^{12}$ Department of Physics and Astronomy, University of Leicester, Leicester, UK
}

Correspondence to: M. Parrington (mark.parrington@ed.ac.uk)

Received: 26 December 2012 - Published in Atmos. Chem. Phys. Discuss.: 17 January 2013

Revised: 24 June 2013 - Accepted: 25 June 2013 - Published: 1 August 2013

\begin{abstract}
We present an analysis of ozone $\left(\mathrm{O}_{3}\right)$ photochemistry observed by aircraft measurements of boreal biomass burning plumes over eastern Canada in the summer of 2011. Measurements of $\mathrm{O}_{3}$ and a number of key chemical species associated with $\mathrm{O}_{3}$ photochemistry, including non-methane hydrocarbons (NMHCs), nitrogen oxides $\left(\mathrm{NO}_{\mathrm{x}}\right)$ and total nitrogen containing species $\left(\mathrm{NO}_{\mathrm{y}}\right)$, were made from the UK FAAM BAe-146 research aircraft as part of the "quantifying the impact of BOReal forest fires on Tropospheric oxidants over the Atlantic using Aircraft and Satellites" (BORTAS) experiment between 12 July and 3 August 2011. The location and timing of the aircraft measurements put BORTAS into a unique position to sample biomass burning plumes from the same source region in Northwestern Ontario with a range of ages. We found that $\mathrm{O}_{3}$ mixing ratios measured in biomass burning plumes were indistinguishable from nonplume measurements, but evaluating them in relationship to measurements of carbon monoxide (CO), total alkyl nitrates $(\Sigma \mathrm{AN})$ and the surrogate species $\mathrm{NO}_{\mathrm{z}}\left(=\mathrm{NO}_{\mathrm{y}}-\mathrm{NO}_{\mathrm{x}}\right)$ revealed that the potential for $\mathrm{O}_{3}$ production increased with plume age. We used NMHC ratios to estimate photochemi-
\end{abstract}

cal ages of the observed biomass burning plumes between 0 and 10 days. The BORTAS measurements provided a wide dynamic range of $\mathrm{O}_{3}$ production in the sampled biomass burning plumes with $\Delta \mathrm{O}_{3} / \Delta \mathrm{CO}$ enhancement ratios increasing from $0.020 \pm 0.008 \mathrm{ppbvpbv}^{-1}$ in plumes with photochemical ages less than 2 days to $0.55 \pm 0.29 \mathrm{ppbv} \mathrm{ppv}^{-1}$ in plumes with photochemical ages greater than 5 days. We found that the main contributing factor to the variability in the $\Delta \mathrm{O}_{3} / \Delta \mathrm{CO}$ enhancement ratio was $\Delta \mathrm{CO}$ in plumes with photochemical ages less than 4 days, and that was a transition to $\Delta \mathrm{O}_{3}$ becoming the main contributing factor in plumes with ages greater than 4 days. In comparing $\mathrm{O}_{3}$ mixing ratios with components of the $\mathrm{NO}_{\mathrm{y}}$ budget, we observed that plumes with ages between 2 and 4 days were characterised by high aerosol loading, relative humidity greater than $40 \%$, and low ozone production efficiency (OPE) of $7.7 \pm 3.5 \mathrm{ppbv} \mathrm{ppbv}^{-1}$ relative to $\Sigma \mathrm{AN}$ and $1.6 \pm 0.9 \mathrm{ppbv} \mathrm{ppbv}^{-1}$ relative to $\mathrm{NO}_{\mathrm{z}}$. In plumes with ages greater than 4 days, OPE increased to $472 \pm 28 \mathrm{ppbv} \mathrm{ppbv}^{-1}$ relative to $\Sigma A N$ and $155 \pm 5 \mathrm{ppbvppbv}^{-1}$ relative to $\mathrm{NO}_{\mathrm{z}}$. From the BORTAS measurements we estimated that aged 
plumes with low aerosol loading were close to being in photostationary steady state and $\mathrm{O}_{3}$ production in younger plumes was inhibited by high aerosol loading and greater production of $\Sigma$ AN relative to $\mathrm{O}_{3}$. The BORTAS measurements of $\mathrm{O}_{3}$ photochemistry in boreal biomass burning plumes were found to be consistent with previous summertime aircraft measurements made over the same region during the Arctic Research of the Composition of the Troposphere (ARCTAS-B) in 2008 and Atmospheric Boundary Layer Experiment (ABLE 3B) in 1990.

\section{Introduction}

The quantifying the impact of BOReal forest fires on Tropospheric oxidants over the Atlantic using Aircraft and Satellites (BORTAS) experiment was conducted in two phases: July-August 2010 (phase A) and 2011 (phase B) (Palmer et al., 2013). The overarching objective of BORTAS was to better understand the chemical evolution of plumes emitted from wildfires in boreal regions, with a particular emphasis on the net production of tropospheric $\mathrm{O}_{3}$ and downwind impacts on air quality. The first phase of the experiment (BORTAS-A) comprised of ground-based, ozonesonde, and satellite measurements over eastern Canada in the summer of 2010, the results from which were reported by Parrington et al. (2012). The second phase of the experiment (BORTASB) was an aircraft measurement campaign based out of Halifax, Nova Scotia, Canada, between 12 July and 3 August 2011, supported by ground-based, ozonesonde, and satellite measurements. An overview of the BORTAS-B campaign is given by Palmer et al. (2013). In this paper we analyse $\mathrm{O}_{3}$ photochemistry in the biomass burning plumes sampled by the aircraft during BORTAS-B.

Tropospheric $\mathrm{O}_{3}$ is a secondary pollutant formed by the photo-oxidation of carbon monoxide (CO) and volatile organic compounds (VOCs) in the presence of nitrogen oxides $\left(\mathrm{NO}_{\mathrm{x}}\right)$ and transport from the stratosphere. Removal of $\mathrm{O}_{3}$ from the troposphere is through dry deposition and photochemical destruction. Tropospheric $\mathrm{O}_{3}$ plays an important role in the contexts of climate and air quality. Emissions of $\mathrm{O}_{3}$ precursors (i.e. $\mathrm{NO}_{\mathrm{x}}$ and VOCs) can be anthropogenic in origin and can also have natural sources such as biogenic processes and biomass burning. A number of previous measurement campaigns have made in situ observations of photochemistry within boreal biomass burning outflow and evaluated the associated $\mathrm{O}_{3}$ production and loss. The NASA Atmospheric Boundary Layer Experiment (ABLE) included two high-latitude aircraft measurement campaigns in the summers of 1988 (ABLE 3A) and 1990 (ABLE 3B) (Harriss et al., 1992, 1994). Analysis of the ABLE 3A measurements, made over northern and western Alaska, found $\mathrm{O}_{3}$ production in haze layers associated with fires to be inefficient with less than 0.1 molecules of $\mathrm{O}_{3}$ formed per molecule of CO (Wofsy et al., 1992). However, the ABLE 3B measurements, made over central and eastern Canada, observed $\mathrm{O}_{3}$ enhancements of 5-15 ppbv in aged ( $>2$ days) biomass burning plumes (Anderson et al., 1994). Aircraft measurements made over the North Atlantic Ocean during the Intercontinental Transport of Ozone and Precursors (ITOP) campaign (Lewis et al., 2007), which was part of the wider International Consortium for Atmospheric Research on Transport and Transformation (ICARTT) (Fehsenfeld et al., 2006) in the summer of 2004, sampled biomass burning plumes associated with fires in Alaska. Examples of elevated $\mathrm{O}_{3}$ were observed in individual plumes with elevated $\mathrm{CO}$ during ITOP but there was no single canonical relationship (Lewis et al., 2007). More recently the NASA Arctic Research of the Composition of the Troposphere from Aircraft and Satellites (ARCTAS) campaign in the spring and summer of 2008 made measurements of biomass burning plumes in central Canada. Analysis of the ARCTAS aircraft measurements showed little evidence for $\mathrm{O}_{3}$ formation within the plumes (Alvarado et al., 2010) other than when the plumes were mixed with outflow from urban pollution (Singh et al., 2010). Ground-based measurements of outflow from boreal biomass burning have also been routinely made at the Pico Mountain Observatory in the mid-Atlantic (Lapina et al., 2006; Val Martin et al., 2006; Helmig et al., 2008). Years with high boreal fire activity have been shown to increase $\mathrm{O}_{3}$ mixing ratios in the free troposphere over this site by up to $10 \mathrm{ppbv}$ (Lapina et al., 2006) with photochemically aged biomass burning plumes influencing tropospheric oxidant chemistry after 1-2 weeks of transport to the region (Helmig et al., 2008).

Model analyses of photochemistry in boreal biomass burning plumes have also been performed to evaluate $\mathrm{O}_{3}$ production and loss. Mauzerall et al. (1996) performed 1-D model simulations to calculate in situ production and loss of $\mathrm{O}_{3}$ based on the ABLE 3B measurements in the summer of 1990. They found biomass burning emissions to be a relatively negligible, contributing less than $2 \%$ to the calculated $\mathrm{O}_{3}$ budget. McKeen et al. (2001) used a 3-D chemistry transport model (CTM) to evaluate the influence of Canadian biomass burning emissions on $\mathrm{O}_{3}$ production over northeastern USA using measurements made from the National Oceanographic and Atmospheric Administration (NOAA) WP-3 aircraft in the summer of $1995 . \mathrm{O}_{3}$ enhancements of between 10 and $30 \mathrm{ppbv}$ throughout the central and eastern US were attributed to the fires, with the model simulations being sensitive to $\mathrm{NO}_{\mathrm{X}} / \mathrm{CO}$ and $\mathrm{VOC} / \mathrm{CO}$ emission ratios. The influence of emissions from forest fires in Alaska and Canada on tropospheric $\mathrm{O}_{3}$ production during summer 2004 was the subject of model studies by Pfister et al. (2006); Real et al. (2007); Cook et al. (2007). Pfister et al. (2006) utilised the MOZART-4 CTM to evaluate $\mathrm{O}_{3}$ production in the outflow from fires in Alaska during summer of 2004 with measurements made from aircraft during the ICARTT campaign and at the Pico Mountain Observatory. They reported $\mathrm{O}_{3}$ 
enhancements relative to $\mathrm{CO}$ of $0.25 \mathrm{ppbv}_{\mathrm{ppbv}}{ }^{-1}$, contributing approximately $3 \%$ of the Northern Hemispheric tropospheric $\mathrm{O}_{3}$ budget. Lagrangian model studies of the outflow over the North Atlantic Ocean (Real et al., 2007) reported that although an $\mathrm{O}_{3}$ enhancement of $17 \mathrm{ppbv}$ was observed after 5 days, net $\mathrm{O}_{3}$ loss could occur in the plumes due to biomass burning aerosols in the plume reducing the photolysis rates of $\mathrm{O}_{3}$ and $\mathrm{NO}_{2}$.

An overview of observed and model estimates of $\mathrm{O}_{3}$ production in boreal biomass burning plumes was recently presented by Jaffe and Wigder (2012). A common feature of observation and model studies of $\mathrm{O}_{3}$ production in biomass burning outflow is the use of $\mathrm{O}_{3}$ enhancement ratios relative to $\mathrm{CO}\left(\Delta \mathrm{O}_{3} / \Delta \mathrm{CO}\right)$ to determine $\mathrm{O}_{3}$ production. Jaffe and Wigder (2012) broadly showed that the $\Delta \mathrm{O}_{3} / \Delta \mathrm{CO}$ ratio increases with plume age. In this paper we diagnose $\mathrm{O}_{3}$ production in biomass burning plumes using in situ aircraft measurements made over eastern Canada in the summer of 2011. We evaluate a number of different metrics, including $\Delta \mathrm{O}_{3} / \Delta \mathrm{CO}$ and $\mathrm{O}_{3}$ production efficiency relative to the $\mathrm{NO}_{\mathrm{y}}$ budget. An overview of the aircraft measurements and chemical processes influencing $\mathrm{O}_{3}$ photochemistry are presented in Sect. 2. Section 3 presents the $\mathrm{O}_{3}$ distribution over eastern Canada observed by the aircraft over the campaign period. Section 4 presents an analysis of observed plume photochemistry using photochemical age calculations derived from $\mathrm{NMHC}$ ratios, $\mathrm{O}_{3}$ production efficiencies relative to $\mathrm{NO}_{\mathrm{y}}$ partitioning, and photostationary steady state calculations. We conclude in Sect. 5.

\section{Airborne photochemical measurements during BORTAS-B}

In this section we present a brief overview of tropospheric $\mathrm{O}_{3}$ photochemistry and the relevant measurements made from the BAe-146 aircraft during the BORTAS-B aircraft measurement campaign, which are used in our analysis.

\subsection{Plume photochemistry}

The simplest model of $\mathrm{O}_{3}$ photochemistry in the atmosphere can be represented by the rapid oxidation of nitrogen oxides, $\mathrm{NO}_{\mathrm{x}}$, which represents the sum of nitric oxide (NO) and nitrogen dioxide $\left(\mathrm{NO}_{2}\right)$, in the presence of sunlight through the following null cycle:

$\mathrm{NO}+\mathrm{O}_{3} \rightarrow \mathrm{NO}_{2}+\mathrm{O}_{2}$

$\mathrm{NO}_{2}+h v \rightarrow \mathrm{NO}+\mathrm{O}$

$\mathrm{O}+\mathrm{O}_{2} \stackrel{M}{\rightarrow} \mathrm{O}_{3}$.

In polluted air masses such as biomass burning plumes, perturbations of this cycle through additional reactions of NO with peroxy radicals $\left(\mathrm{RO}_{2}\right.$ or $\left.\mathrm{HO}_{2}\right)$ produced by the oxidation of VOCs provide additional pathways for converting $\mathrm{NO}_{\mathrm{x}}$ into $\mathrm{O}_{3}$. Figure 1 shows a schematic of the simplified

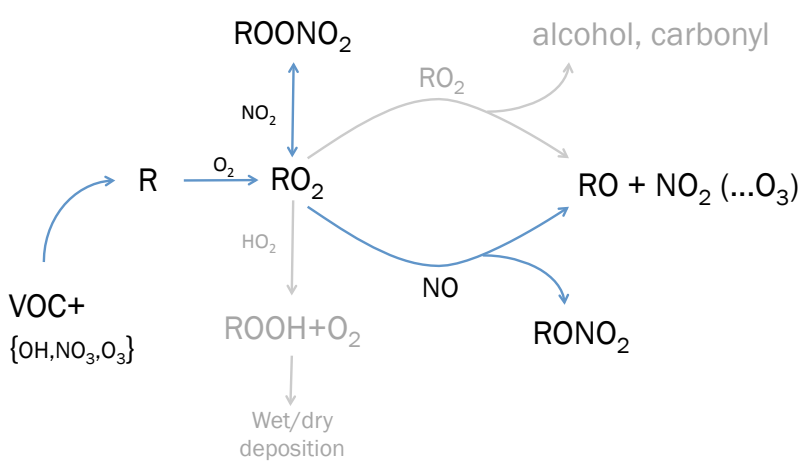

Fig. 1. Schematic of the atmospheric $\mathrm{O}_{3}-\mathrm{NO}_{\mathrm{x}}$-hydrocarbon chemistry cycle studied by BORTAS.

$\mathrm{O}_{3}-\mathrm{NO}_{\mathrm{x}}-\mathrm{VOC}$ chemistry in the atmosphere. The chain of reactions leading to $\mathrm{O}_{3}$ formation is initiated by the photooxidation of a VOC (RH) and its rapid subsequent reaction with molecular oxygen to produce alkyl peroxy radicals $\left(\mathrm{RO}_{2}\right)$, for example

$\mathrm{RH}+\mathrm{OH} \stackrel{\mathrm{O}_{2}}{\rightarrow} \mathrm{RO}_{2}+\mathrm{H}_{2} \mathrm{O}$.

Under tropospheric conditions, as indicated by the blue arrows in Fig. 1, alkyl peroxy radicals can react with $\mathrm{NO}_{2}$ via a three body reaction to form peroxynitrates $\left(\mathrm{RO}_{2} \mathrm{NO}_{2}\right)$ :

$\mathrm{RO}_{2}+\mathrm{NO}_{2} \stackrel{M}{\rightarrow} \mathrm{RO}_{2} \mathrm{NO}_{2}$,

which will decompose back into the constituent $\mathrm{RO}_{2}$ and $\mathrm{NO}_{2}$ under the right environmental conditions (i.e. near surface temperatures) but can also be subject to transport away from the source region as they are thermally stable at lower temperatures, such as those in the free troposphere.

Peroxy radicals are also subject to reaction with $\mathrm{NO}$ and can follow two different pathways:

$\mathrm{RO}_{2}+\mathrm{NO} \rightarrow \mathrm{RO}+\mathrm{NO}_{2}$

$\mathrm{RO}_{2}+\mathrm{NO} \stackrel{M}{\rightarrow} \mathrm{RONO}_{2}$

Reaction (R6) results in the formation of $\mathrm{O}_{3}$ molecules via photolysis of $\mathrm{NO}_{2}$. Comparison of reactions (R6) and (R7) indicates that $\mathrm{O}_{3}$ production in biomass burning plumes initiated by photo-oxidation of VOCs is in competition with production of alkyl nitrates $\left(\mathrm{RONO}_{2}\right)$; evaluating the relationship between the measured $\mathrm{O}_{3}$ and $\mathrm{RONO}_{2}$ mixing ratios provides an indication of the potential for $\mathrm{O}_{3}$ production related to the above mechanism (e.g. Perring et al., 2010).

The potential of the above reactions to produce $\mathrm{O}_{3}$ in biomass burning plumes is dependent on the availability of nitrogen oxides, $\mathrm{NO}_{\mathrm{x}}\left(=\mathrm{NO}+\mathrm{NO}_{2}\right)$. A surrogate species, $\mathrm{NO}_{\mathrm{y}}$, is used to represent the sum of all reactive and oxidised nitrogen species in an air mass: $\mathrm{NO}_{\mathrm{y}}=\mathrm{NO}_{\mathrm{x}}+\Sigma \mathrm{RO}_{2} \mathrm{NO}_{2}+\Sigma \mathrm{RONO}_{2}+\mathrm{HNO}_{3}+$ $\mathrm{HONO}+\mathrm{NO}_{3}+2 \mathrm{~N}_{2} \mathrm{O}_{5}+\mathrm{NO}_{3}^{-}$), where $\Sigma \mathrm{RO}_{2} \mathrm{NO}_{2}$ represents the total peroxynitrates $(\Sigma \mathrm{PN})$ and $\Sigma \mathrm{RONO}_{2}$ represents the total alkyl nitrates ( $\Sigma$ AN) (e.g. Day et al., 2003). 
A second surrogate species, $\mathrm{NO}_{\mathrm{z}}\left(=\mathrm{NO}_{\mathrm{y}}-\mathrm{NO}_{\mathrm{x}}\right)$, can be defined that represents the sum of the photo-oxidation products of $\mathrm{NO}_{\mathrm{x}}$ (Olszyna et al., 1994). Since $\mathrm{NO}_{\mathrm{y}}$ is representative of all $\mathrm{NO}_{\mathrm{x}}$ emissions, $\mathrm{NO}_{\mathrm{z}}$ provides a measure of the number of $\mathrm{NO}_{\mathrm{x}}$ molecules that have undergone photo-oxidation. Several studies have shown that the $\mathrm{O}_{3}$ abundance in polluted air masses is linearly related to the abundance of $\mathrm{NO}_{\mathrm{z}}$ (e.g., Trainer et al., 1993; Kleinman, 2000). The enhancement of $\mathrm{O}_{3}$ abundance relative to $\mathrm{NO}_{\mathrm{z}}$ (i.e. $\Delta \mathrm{O}_{3} / \Delta \mathrm{NO}_{\mathrm{z}}$ ) provides a measure of $\mathrm{O}_{3}$ production related to photo-oxidation of $\mathrm{NO}_{\mathrm{x}}$ molecules, sometimes referred to as the ozone production efficiency (OPE) (Ryerson et al., 1998; Rickard et al., 2002).

\subsection{BORTAS measurements}

Measurements of the key tracers relevant to the $\mathrm{O}_{3}$ photochemistry outlined above were made from the BAe-146 aircraft over the course of the BORTAS-B measurement campaign. Full details of the BAe-146 payload are presented in Table 2 of Palmer et al. (2013) and we provide here brief details of the measurements used in this study.

Measurements of $\mathrm{O}_{3}$ were made using a TECO 49 ultraviolet absorption instrument (Wilson and Birks, 2006) operated by the UK Facility for Airborne Atmospheric Measurements (FAAM) with an average time of $3 \mathrm{~Hz}$, at a precision of $1 \mathrm{ppbv}$ and accuracy of $\pm 5 \%$. Measurements used for identification of biomass burning plume air masses included acetonitrile $\left(\mathrm{CH}_{3} \mathrm{CN}\right)$ and $\mathrm{CO}$. A proton transfer reaction mass spectrometer (PTR-MS) (Murphy et al., 2010) provided measurements of $\mathrm{CH}_{3} \mathrm{CN}$ with an average time of $1 \mathrm{~s}$ and mean precision of $37 \mathrm{pptv}$ over all BORTAS flights. $\mathrm{CO}$ was measured using a vacuum-UV resonance fluorescence instrument (Gerbig et al., 1999) with an average time of $1 \mathrm{~s}$, precision of $1 \mathrm{ppbv}$, and accuracy of $3 \%$. We determined the aerosol loading within the sampled plume air with measurements of refractory black carbon using a single particle soot photometer (SP2) and measurements of total scattering coefficient at $550 \mathrm{~nm}$ using a TSI Inc. 3563 threewavelength nephelometer (Anderson and Ogren, 1998). The SP2 uses laser-induced incandescence to measure refractory black carbon on a single particle basis (Schwarz et al., 2006); the inlet and instrumental setup on the BAe-146 are described by McMeeking et al. (2010). The statistical uncertainty in $\mathrm{BC}$ mass concentration was $5 \%$ for an average time of $15 \mathrm{~s}$, and accuracy was within $20 \%$ due to possible differences between the instrumental response to biomass burning BC and the calibrant (Laborde et al., 2012). Measurement of $\mathrm{NO}_{2}$ photolysis rates were made using upper and lower fixed bandwidth radiometers at wavelengths predominantly between 208 and $500 \mathrm{~nm}$, at a frequency of $1 \mathrm{~Hz}$ and with accuracy of $10 \%$ (Volz-Thomas et al., 1996). Measurements of VOCs used in this study were made using a dual channel gas chromatograph system with flame ionisation detection (GC-FID) (Hopkins et al., 2003, 2011) to analyse whole air canister samples taken during each flight. Each canister sample was taken over a $30 \mathrm{~s}$ period at points of particular interest along the flight track. The precision and accuracy of the GC-FID measurements are species dependent but typical values are $1-5 \mathrm{pptv}$ and $5 \%$, respectively. Measurements of $\mathrm{NO}$ and $\mathrm{NO}_{2}$ were made using a single channel chemiluminesence instrument manufactured by Air Quality Design (AQD) Inc., USA, as described by Lee et al. (2009). The accuracy of the AQD NO and $\mathrm{NO}_{2}$ measurements was 10 pptv. Measurements of $\mathrm{NO}_{2}$, total $\mathrm{NO}_{\mathrm{y}}$, total peroxyacetyl nitrates $\left(\Sigma \mathrm{PN}=\Sigma \mathrm{RO}_{2} \mathrm{NO}_{2}\right)$, and total alkyl nitrates $\left(\Sigma \mathrm{AN}=\Sigma \mathrm{RONO}_{2}\right)$ were made using a Thermal Dissociation-Laser Induced Fluorescence (TD-LIF) instrument (Dari-Salisburgo et al., 2009; Di Carlo et al., 2013) with accuracies of $10 \%, 22 \%, 34 \%$, and $46 \%$, respectively.

For the analysis presented here we calculated mixing ratios of $\mathrm{NO}_{\mathrm{x}}$, and subsequently $\mathrm{NO}_{\mathrm{z}}$, from the aircraft measurements of $\mathrm{NO}, \mathrm{NO}_{2}$ and $\mathrm{NO}_{\mathrm{y}}$ described above. The $\mathrm{NO}_{\mathrm{x}}$ mixing ratio was calculated using $\mathrm{NO}$ measured by the AQD instrument and $\mathrm{NO}_{2}$ measured by the TD-LIF instrument. The AQD instrument measures $\mathrm{NO}_{2}$ indirectly, after it has undergone photo dissociation to form $\mathrm{NO}$ in the presence of UV radiation (Lee et al., 2009), whereas the TD-LIF instrument measures $\mathrm{NO}_{2}$ directly; we use the TD-LIF in the $\mathrm{NO}_{\mathrm{x}}$ calculation to reduce uncertainties and possible interferences. $\mathrm{NO}_{\mathrm{z}}$ was then calculated by subtracting the AQD/LIF $\mathrm{NO}_{\mathrm{x}}$ values from the LIF total $\mathrm{NO}_{\mathrm{y}}$ measurements. We calculated average uncertainties of $13 \pm 6 \%$ in the range $6-45 \%$ for $\mathrm{NO}_{\mathrm{x}}$ and $51 \pm 4 \%$ in the range $47-84 \%$ for $\mathrm{NO}_{\mathrm{z}}$. For both $\mathrm{NO}_{\mathrm{x}}$ and $\mathrm{NO}_{z}$, calculated uncertainties more than $2 \sigma$ standard deviations above the average occurred for approximately $5 \%$ of the plume measurements with the lowest calculated $\mathrm{NO}_{\mathrm{x}}$ and $\mathrm{NO}_{\mathrm{z}}$ mixing ratios.

To distinguish measurements made in biomass burning plumes from those made in clean air, we use the threshold of $150 \mathrm{pptv}$ of $\mathrm{CH}_{3} \mathrm{CN}$ determined by Palmer et al. (2013) from the 99 percentile of measurements made on flight B625. $\mathrm{CH}_{3} \mathrm{CN}$ is predominantly emitted from biomass burning and removed from the atmosphere through uptake by the oceans and reaction with $\mathrm{OH}$, with an atmospheric lifetime of approximately 25 days (Bange and Williams, 2000); therefore, $\mathrm{CH}_{3} \mathrm{CN}$ is an excellent tracer for identifying plume measurements.

\section{Observed $\mathrm{O}_{3}$ distribution over eastern Canada}

In this section we present an overview of the $\mathrm{O}_{3}$ distribution observed from the BAe-146 aircraft during the BORTAS$\mathrm{B}$ measurement campaign. Figure 2 shows the relative frequency distribution of $\mathrm{O}_{3}$ mixing ratios, divided into $1 \mathrm{ppbv}$ bins, measured from the BAe-146 during the eleven research flights undertaken 15-31 July 2011 (Table 1). The frequency distribution of the $\mathrm{O}_{3}$ measurements made both in and out of biomass burning plumes shows two peaks at approximately 


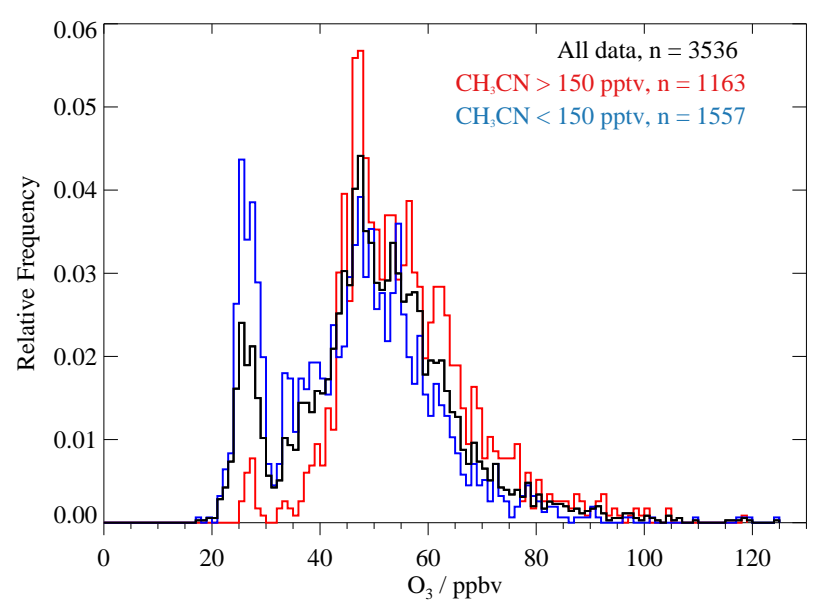

Fig. 2. Frequency distribution of $\mathrm{O}_{3}$ mixing ratios measured from the BAe-146 on all research flights during the BORTAS campaign period (15 to 31 July 2011). Frequencies are calculated for $1 \mathrm{ppbv}$ bins. The black line shows the distribution of all the measured $\mathrm{O}_{3}$ mixing ratios, the red line shows the distribution of measurements identified as biomass burning plumes using a threshold of $\mathrm{CH}_{3} \mathrm{CN}$ mixing ratios greater than $150 \mathrm{pptv}$, and the blue line shows measurements made in air masses with $\mathrm{CH}_{3} \mathrm{CN}$ mixing ratios less than 150 pptv. The number of data points, $n$, for each distribution are shown in the legend.

25 and 50 ppbv. The peak in $\mathrm{O}_{3}$ mixing ratio at $25 \mathrm{ppbv}$ is attributable to measurements made at altitudes below $3 \mathrm{~km}$. The $\mathrm{O}_{3}$ measurements made during BORTAS-B show a similar distribution to that observed over central and eastern Canada during the ABLE 3B measurement campaign in the summer of 1990 (Anderson et al., 1994).

The statistical distribution of $\mathrm{O}_{3}$ mixing ratios measured on each of the BORTAS campaign flights (Table 1) is shown in Fig. 3a. Each flight shows a wide range of measured $\mathrm{O}_{3}$ mixing ratios between 20 and 125 ppbv, reflecting the variability in $\mathrm{O}_{3}$ over the geographical area and altitude ranges covered by the aircraft over the course of the campaign. The mean $\mathrm{O}_{3}$ mixing ratio measured over the whole campaign was $50 \mathrm{ppbv}$, which was reduced to $46 \mathrm{ppbv}$ for measurements made in non-plume $\left(\mathrm{CH}_{3} \mathrm{CN}<150 \mathrm{pptv}\right)$ air masses and increased to $57 \mathrm{ppbv}$ for plume air measurements. In general, $\mathrm{O}_{3}$ mixing ratios were less than the campaign mean of the plume measurements. Figure $3 \mathrm{~b}$ shows the statistical distribution of the measured $\mathrm{O}_{3}$ mixing ratios as a function of the aircraft GPS altitude, divided into $1 \mathrm{~km}$ wide bins. Using the medians for each altitude bin, the $\mathrm{O}_{3}$ mixing ratio increased from less than $40 \mathrm{ppbv}$ between 0.5 and $1.5 \mathrm{~km}$ to approximately $60 \mathrm{ppbv}$ between 7.5 and $8.5 \mathrm{~km}$. Plume measurements were higher on average than non-plume measurements, apart from the altitude range between 4.5 and $5.5 \mathrm{~km}$, and measurements were typically less than the campaign mean of the plume data below $5.5 \mathrm{~km}$. Three research flights (B621, B629 and B630) measured $\mathrm{O}_{3}$ mixing ratios that were (a)

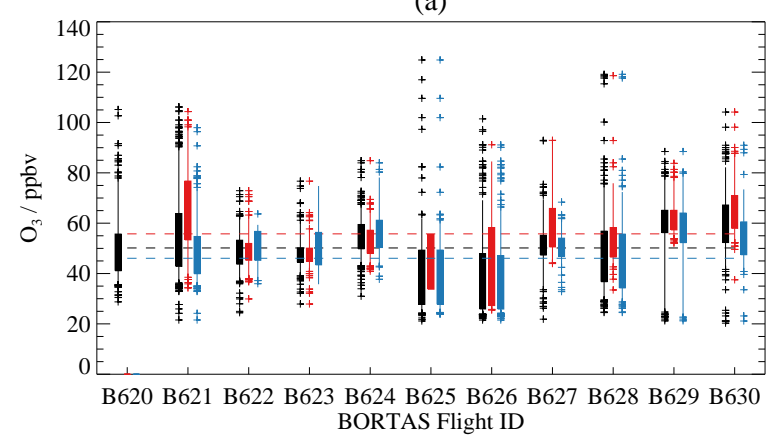

(b)

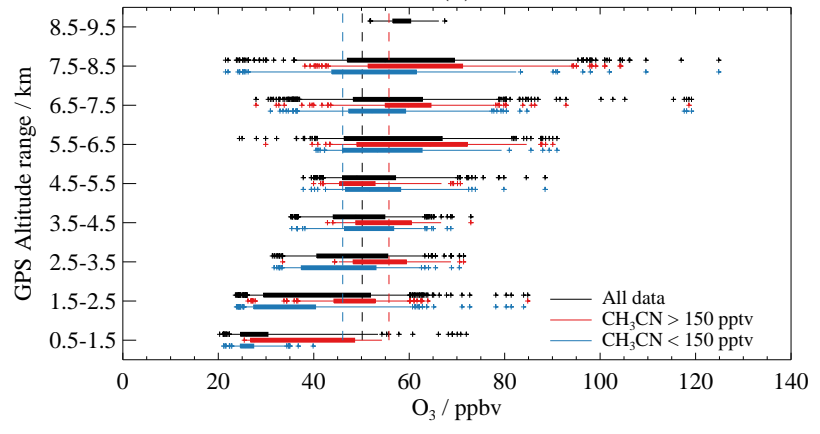

Fig. 3. Box and whisker plots showing the statistical distribution of $\mathrm{O}_{3}$ measurements made from the BAe-146 during BORTAS as a function of (a) research flight (see Table 1 and Palmer et al., 2013), and (b) aircraft GPS altitude. In both plots solid boxes show the range of the 25th to 75 th percentiles and whiskers show the range of the 5th to 95th percentiles with outliers shown as plus symbols. Black boxes and whiskers show all measured values, red boxes and whiskers show plume measurements determined from measured $\mathrm{CH}_{3} \mathrm{CN}$ mixing ratios in excess of $150 \mathrm{pptv}$, and blue boxes and whiskers show non-plume measurements (i.e. $\mathrm{CH}_{3} \mathrm{CN}$ less than 150 pptv). Dashed lines in each panel indicate the campaign mean $\mathrm{O}_{3}$ mixing ratio for each group of data points.

on average greater than the campaign mean. These measurements were typically made at higher altitudes, above $5.5 \mathrm{~km}$, as reflected in Fig. 3b. A number of outlying $\mathrm{O}_{3}$ mixing ratios were made below the 5 th percentile and above the 95 th percentile of the observed statistics on each flight, reflecting the wide range of altitudes over which the measurements were made on each flight.

\section{Observed boreal biomass burning outflow}

In this section we evaluate the processes influencing the $\mathrm{O}_{3}$ distribution in biomass burning plume air sampled by the BAe-146 over the course of the BORTAS campaign. Figure 4 shows the relative distributions of $60 \mathrm{~s}$ averaged $\mathrm{O}_{3}$ and $\mathrm{CO}$ mixing ratios measured from the aircraft. Figure 2 shows that there is no discernible difference between $\mathrm{O}_{3}$ measurements made in the plume air and those in clean air. CO mixing ratios in plumes range from 64 to 930 ppbv. For CO mixing 
Table 1. Flight IDs, dates, and location of research flights made by the BAe-146 during the BORTAS aircraft measurement campaign in 2011. The relative locations of each flight are shown in Palmer et al. (2013).

\begin{tabular}{ccl}
\hline Flight ID & Date (Day of Year) & Location \\
\hline B620 & 15 July (196) & Eastern Quebec \\
B621 & 18 July (199) & Newfoundland and Labrador \\
B622 & 20 July (201) & Southern Quebec \\
B623 & 20 July (201) & Quebec City to Halifax \\
B624 & 21 July (202) & Atlantic Ocean to east of Island of Newfoundland \\
B625 & 24 July (202) & Gulf of St. Lawrence \\
B626 & 26 July (207) & Northwestern Ontario \\
B627 & 27 July (208) & Thunder Bay ON to Goose Bay NL \\
B628 & 28 July (209) & Labrador coast \\
B629 & 31 July (212) & Gulf of St. Lawrence \\
B630 & 31 July (212) & Nova Scotia and Island of Newfoundland \\
\hline
\end{tabular}

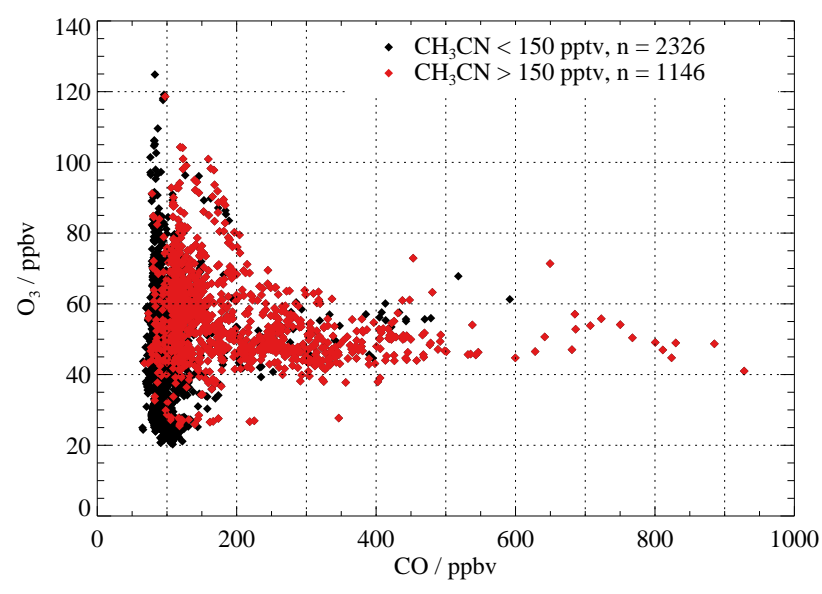

Fig. 4. Scatter plot of $60 \mathrm{~s}$ averaged $\mathrm{O}_{3}$ versus $\mathrm{CO}$ mixing ratios in ppbv measured from the BAe-146 during the BORTAS campaign period. Black symbols show all measured data and red symbols show the data points identified as biomass burning outflow. The number of data points, $n$, are shown in the legend.

ratios in excess of $300 \mathrm{ppbv}, \mathrm{O}_{3}$ mixing ratios lie within a range between approximately 40 and $60 \mathrm{ppbv}$. In the following subsections we examine $\mathrm{O}_{3}$ production and photochemistry measured in boreal biomass burning plumes.

\subsection{Photochemical ageing of biomass burning plumes}

We first investigate photochemical processing within biomass burning plumes sampled by the aircraft through calculation of a photochemical age, i.e. the time taken for a particular measured tracer to be removed chemically from an air mass after emission. We calculate photochemical ages based on ratios of non-methane hydrocarbons (NMHCs) (Parrish et al., 2007). The NMHCs used in this calculation are ethane $\left(\mathrm{C}_{2} \mathrm{H}_{6}\right)$, propane $\left(\mathrm{C}_{3} \mathrm{H}_{8}\right)$ and $n$-butane $\left(\mathrm{C}_{4} \mathrm{H}_{10}\right)$ measured by GC-FID from whole air canister samples taken over the course of the BORTAS campaign. Figure 5 shows

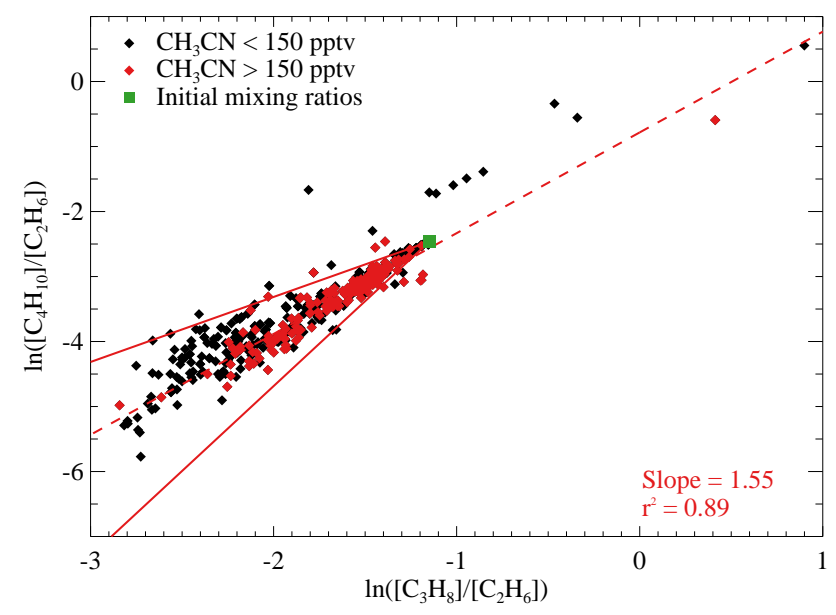

Fig. 5. Scatter plot of the natural logarithms of the ratios of $\left[\mathrm{C}_{4} \mathrm{H}_{10}\right]:\left[\mathrm{C}_{2} \mathrm{H}_{6}\right]$ and $\left[\mathrm{C}_{3} \mathrm{H}_{8}\right]:\left[\mathrm{C}_{2} \mathrm{H}_{6}\right]$ measured from whole air canister samples taken by the BAe-146 during the BORTAS campaign period. All measured data are shown as black diamonds with red diamonds showing measurements made in boreal biomass burning plumes. The green square shows the ratios of the initial concentrations of the three alkanes used in the plot, estimated from BORTAS flight B626 over the burning source region in Northwestern Ontario. The solid red bounding lines represent the behaviour of the hydrocarbon ratios: the steeper slope assumes only oxidation of the alkanes with $\mathrm{OH}$ (kinetic slope); the shallower slope assumes only mixing of fresh emissions with background air (mixing slope). The dashed red line shows a linear fit to the plume measurements.

the relationship between natural logarithms of the observed $\left[\mathrm{C}_{4} \mathrm{H}_{10}\right]:\left[\mathrm{C}_{2} \mathrm{H}_{6}\right]$ and $\left[\mathrm{C}_{3} \mathrm{H}_{8}\right]:\left[\mathrm{C}_{2} \mathrm{H}_{6}\right]$ ratios, where $[\mathrm{X}]$ represents the concentration of NMHC X. The ratio of initial mixing ratios for each NMHC pair are determined from flight B626 over Northwestern Ontario on 26 July, which was the main source of biomass burning early in the campaign with fires burning 17-19 July. In the absence of detailed combustion information of these fires, we assume that 
the higher values of the natural logarithm of the NMHC ratios from flight $\mathrm{B} 626$ are representative of the ratios of the freshest emissions of these NMHCs, and are shown as the solid green square in Fig. 5. We also assume that this ratio is representative of the initial mixing ratios of these NMHCs emitted from forest fire emissions across boreal North America, based on the similarity of vegetation cover over the region (Latifovic et al., 2004). The majority of NMHC ratios measured in biomass burning plumes during BORTAS lie to the left and below this point, indicating that the estimated initial concentrations are a suitable reference point for calculating the relative photochemical ageing of the biomass burning plumes sampled during the campaign. Following Parrish et al. (2007), we show bounding limits for oxidation by $\mathrm{OH}$ and dilution or mixing of fresh emissions into aged air masses as solid lines in Fig. 5. The steeper of these lines represents ageing of plume air if oxidation of the NMHCs was the only process influencing their concentration. This is sometimes referred to as the "kinetic" line (Parrish et al., 2007; Helmig et al., 2008), and in our study its slope is calculated from the kinetic reaction rate coefficients of the measured NMHCs with $\mathrm{OH}$. Assuming a typical free tropospheric temperature of $273 \mathrm{~K}$ and taking reaction rate coefficients from Atkinson and Arey (2003), we calculate a kinetic slope of 2.61. The less steep of the solid lines in Fig. 5 can be considered a "dilution" line and represents dilution of a plume, starting with the same initial mixing ratios through mixing with background air that is sufficiently aged so that only the least reactive NMHC (i.e. $\mathrm{C}_{2} \mathrm{H}_{6}$ ) remains at significant concentrations. The mixing causes the ratio of the NMHC ratios to decrease with a slope of unity (Parrish et al., 2007). In general, NMHC ratios calculated from the BORTAS measurements lie between -3 and -1 for $\ln \left(\left[\mathrm{C}_{3} \mathrm{H}_{8}\right] /\left[\mathrm{C}_{2} \mathrm{H}_{6}\right]\right)$ and between -6 and -2.5 for $\ln \left(\left[\mathrm{C}_{4} \mathrm{H}_{10}\right] /\left[\mathrm{C}_{2} \mathrm{H}_{6}\right]\right)$ and are consistent with previous observations of NMHC ratios (Rudolph and Johnen, 1990; Parrish et al., 1992; Jobson et al., 1994; Parrish et al., 2007; Helmig et al., 2008). These data points lie within the bounds of the dilution and kinetic slopes, indicating that NMHC concentrations in the measured air masses were subject to a combination of oxidation and mixing between fresh emissions and background air. This is also consistent with the previous studies listed above and is not unexpected given that the BORTAS measurements were made between $1000-3000 \mathrm{~km}$ downwind of the emission sources. The gradient of the line of best fit to the data is 1.55 , further supporting the assumption that the observations were subject to mixing and photochemical processing. Outliers in Fig. 5, i.e. where $\ln \left(\left[\mathrm{C}_{3} \mathrm{H}_{8}\right] /\left[\mathrm{C}_{2} \mathrm{H}_{6}\right]\right)>-1$ and $\ln \left(\left[\mathrm{C}_{4} \mathrm{H}_{10}\right] /\left[\mathrm{C}_{2} \mathrm{H}_{6}\right]\right)>-2$, show measurements representative of different emission sources and are beyond the scope of the work presented here.

We estimate plume ages in days for the plume air masses sampled during the BORTAS campaign using the $\ln \left(\left[\mathrm{C}_{3} \mathrm{H}_{8}\right] /\left[\mathrm{C}_{2} \mathrm{H}_{6}\right]\right)$ ratio and assuming a constant average
$\mathrm{OH}$ concentration of $2 \times 10^{6}$ molecules $\mathrm{cm}^{-3}$. As no $\mathrm{OH}$ measurements were made from the BAe-146 during the campaign, this value was chosen to be representative of a northern mid-latitude summertime $\mathrm{OH}$ concentration (Spivakovsky et al., 2000). Varying the average $\mathrm{OH}$ concentration in the photochemical age calculations from half to double the assumed value would double or halve the age, respectively. The photochemical ages we calculate from the BORTAS measurements using this assumed $\mathrm{OH}$ concentration were similar to transport timescales from the emission source determined by back trajectory calculations (not presented here), providing confidence in our assumption. Estimating the photochemical plume age in this way allows us to compare $\mathrm{O}_{3}$ production in boreal biomass burning plumes measured over the BORTAS campaign to similar measurements used in previous studies.

\section{2 $\mathrm{O}_{3}$ enhancements in biomass burning plumes}

Figure 6 shows the relationships between $\mathrm{O}_{3}$ and $\mathrm{CO}$ measured in biomass burning plumes during the BORTAS measurement campaign to the calculated photochemical ages, sampled at the times of the whole air canister samples. $\mathrm{O}_{3}$ mixing ratios measured in boreal biomass burning plumes, Fig. 6a, show no clear relationship to the calculated photochemical age over the whole BORTAS campaign period. The $\mathrm{O}_{3}$ measurements made on flight B626 are distinguished from those made on the other research flights by mixing ratios less than $30 \mathrm{ppbv}$. It should be noted that the measurements made in biomass burning plumes on flight B626 were made at lower altitudes (below $1.5 \mathrm{~km}$ ) than on other flights. Measurements with higher $\mathrm{CH}_{3} \mathrm{CN}$ mixing ratios typically show moderate $\mathrm{O}_{3}$ mixing ratios between 40 and $70 \mathrm{ppbv}$ with photochemical ages between 1.5 and 4.5 days. The measurements made with lower $\mathrm{CH}_{3} \mathrm{CN}$ exhibit a wider range of $\mathrm{O}_{3}$ mixing ratios, from 40 to $110 \mathrm{ppbv}$, and photochemical ages, from 0 to 10 days. The $\mathrm{CO}$ mixing ratios measured in boreal biomass burning plumes, Fig. 6b, typically show higher values (between 200 and $1100 \mathrm{ppbv}$ ) at photochemical ages of between 2 and 4 days and are coincident with the higher values of $\mathrm{CH}_{3} \mathrm{CN}$. These measurements were made at aircraft altitudes below $3 \mathrm{~km}$ during flights B622-B624 on 20 and 21 July in plumes from the fires in Northwestern Ontario with approximate transport times of 2-3 days, calculated by Lagrangian backward trajectories (not shown). Measurements of CO mixing ratios less than $200 \mathrm{ppbv}$ have a wider range of photochemical ages, between 0 and 10 days. On flight B626, CO mixing ratios were measured between 150 and $400 \mathrm{ppbv}$ with photochemical ages from 0 to 8.5 days.

The relationship between the measured $\mathrm{O}_{3}$ and $\mathrm{CO}$ mixing ratios in boreal biomass burning plumes is shown in Fig. $6 c$ for the data sampled at the times of the whole air canister samples. The distribution is similar to that shown by the red symbols in Fig. 4 for the $60 \mathrm{~s}$ averaged 
(a)

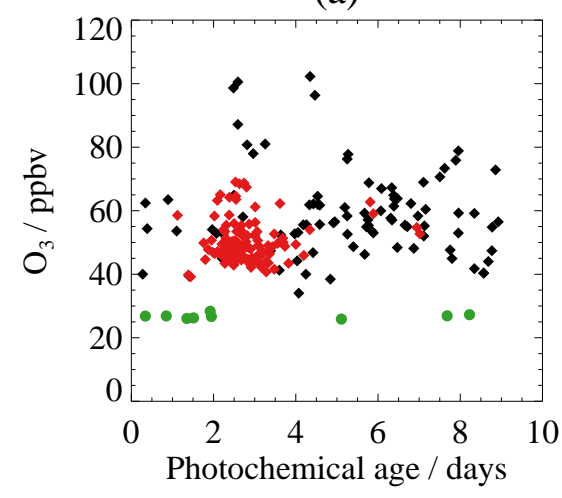

(c)

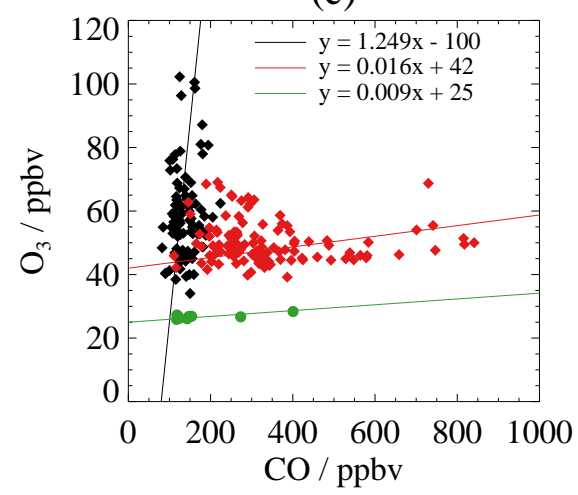

(b)

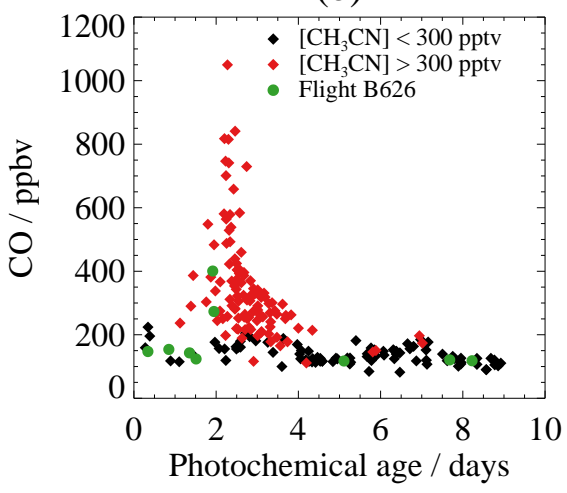

(d)

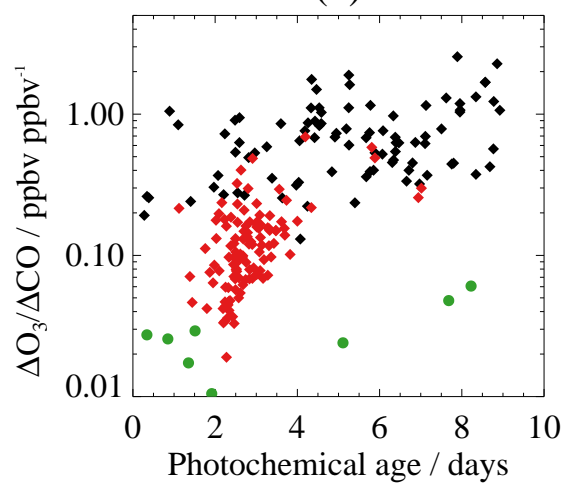

Fig. 6. Relationship between $\mathrm{O}_{3}$ and $\mathrm{CO}$ mixing ratios measured from the BAe-146 and sampled at the WAS measurement times, and photochemical ages calculated from the $\ln \left(\mathrm{C}_{3} \mathrm{H}_{8} / \mathrm{C}_{2} \mathrm{H}_{6}\right)$ ratio in boreal biomass burning plumes throughout the BORTAS-B measurement campaign and assuming an $\mathrm{OH}$ concentration of $2 \times 10^{6}$ molecules $\mathrm{cm}^{-3}$. (a) and (b) show the measured $\mathrm{O}_{3}$ and $\mathrm{CO}$ mixing ratios, respectively, in units of ppbv as a function of the calculated photochemical age in days. (c) shows the scatter of $\mathrm{O}_{3}$ versus $\mathrm{CO}$ with straight lines showing linear fits to each population of data points. (d) shows the enhancement of $\mathrm{O}_{3}$ relative to $\mathrm{CO}\left(\Delta \mathrm{O}_{3} / \Delta \mathrm{CO}\right)$ as a function of photochemical age. In all plots the data are filtered according to their relative abundance of $\mathrm{CH}_{3} \mathrm{CN}$, with black diamonds representing $\mathrm{CH}_{3} \mathrm{CN}$ mixing ratios between 150 and $300 \mathrm{pptv}$ and red diamonds representing $\mathrm{CH}_{3} \mathrm{CN}$ mixing ratios in excess of 300 pptv. Measurements made on flight B626 over the fire region in Northwestern Ontario are treated separately and are represented by green circles.

data. The three populations of data points defined for flight B626, and moderate and high $\mathrm{CH}_{3} \mathrm{CN}$, show clear distinctions from one another. Straight lines fitted to each population and their slopes provide an indication of $\mathrm{O}_{3}$ produced since the fire emissions of $\mathrm{CO}$ and other precursors at the source, i.e. $\Delta \mathrm{O}_{3} / \Delta \mathrm{CO}$ (Parrish et al., 1993; Pfister et al., 2006). Measurements of fresh biomass burning air masses were made during flight B626, indicated by a slope of $0.009 \pm 0.001 \mathrm{ppbv} \mathrm{ppbv}^{-1}$. Of the measurements made on the other BORTAS research flights, those with the highest $\mathrm{CH}_{3} \mathrm{CN}$ mixing ratios were made in moderately fresh plume air masses with photochemical ages of 2-4 days. The gradient of the straight line fitted to these data points is $0.016 \pm 0.001 \mathrm{ppbv} \mathrm{ppbv}^{-1}$, suggesting a slight increase in $\mathrm{O}_{3}$ production downwind of the emission source. Measurements with moderate $\mathrm{CH}_{3} \mathrm{CN}$ are typically more aged (photochemical ages $>4$ days) and indicate increased $\mathrm{O}_{3}$ production relative to the other two populations, as reflected in the gradient of the straight line fitted to these data points of
$1.292 \pm 0.007 \mathrm{ppbv} \mathrm{ppbv}^{-1}$. Figure $6 \mathrm{~d}$ shows enhancement ratios of $\mathrm{O}_{3}$ relative to $\mathrm{CO}$ as a function of photochemical age. Enhancements of $\mathrm{O}_{3}$ and $\mathrm{CO}$ (i.e. $\Delta \mathrm{O}_{3}$ and $\Delta \mathrm{CO}$ ) are calculated relative to background values determined from the distribution of clean air measurements defined by $\mathrm{CH}_{3} \mathrm{CN}$ mixing ratios less than $100 \mathrm{pptv}$ and $\mathrm{CO}$ mixing ratios less than $100 \mathrm{ppbv}$. Average $\mathrm{O}_{3}$ and $\mathrm{CO}$ mixing ratios in the clean air measurements were $42.0 \pm 14.3 \mathrm{ppbv}$ in the range $21.5-$ $124.8 \mathrm{ppbv}$, and $87.8 \pm 6.6 \mathrm{ppbv}$ in the range $70.1-99.9 \mathrm{ppbv}$, respectively. We calculate background $\mathrm{O}_{3}$ and $\mathrm{CO}$ mixing ratios, using the 25th percentile of the distribution of the clean air measurements, to be 25 and 81 ppbv, respectively.

The $\Delta \mathrm{O}_{3} / \Delta \mathrm{CO}$ ratios for the three populations of data show a similar trend to the gradients calculated for the $\mathrm{O}_{3}$ to $\mathrm{CO}$ relationship in Fig. $6 \mathrm{c}$, with the value of $\Delta \mathrm{O}_{3} / \Delta \mathrm{CO}$ increasing from the measurements made on flight B626 through the high $\mathrm{CH}_{3} \mathrm{CN}$ measurements to the moderate $\mathrm{CH}_{3} \mathrm{CN}$ measurements. The measurements made on flight B626 have $\Delta \mathrm{O}_{3} / \Delta \mathrm{CO}$ ratios between approximately 
Table 2. Observed $\Delta \mathrm{O}_{3} / \Delta \mathrm{CO}$ in biomass burning plumes sampled during BORTAS filtered by photochemical age, following Jaffe and Wigder (2012).

\begin{tabular}{|c|c|c|c|c|}
\hline Plume category & $\begin{array}{c}\text { Range of } \Delta \mathrm{O}_{3} / \Delta \mathrm{CO} \text { (ppbv ppbv }{ }^{-1} \text { ) } \\
\text { (no. of measurements) }\end{array}$ & 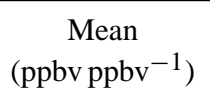 & $\begin{array}{c}\text { Median } \\
\left(\text { ppbv ppbv }^{-1}\right)\end{array}$ & $\begin{array}{l}\text { Standard deviation } \\
\left(\mathrm{ppbv} \mathrm{ppbv}^{-1}\right)\end{array}$ \\
\hline$\leq 2$ days 1 & $0.009-0.029(n=6)$ & 0.020 & 0.027 & 0.009 \\
\hline $2-5$ days $^{2}$ & $0.02-0.69(n=100)$ & 0.13 & 0.12 & 0.10 \\
\hline $2-5$ days $^{3}$ & $0.02-1.76(n=134)$ & 0.27 & 0.15 & 0.31 \\
\hline$\geq 5$ days $^{3}$ & $0.24-2.55(n=52)$ & 0.81 & 0.63 & 0.52 \\
\hline$\geq 5$ days 4 & $0.24-1.89(n=50)$ & 0.75 & 0.63 & 0.41 \\
\hline
\end{tabular}

${ }^{1}$ Flight B626;

${ }^{2}\left[\mathrm{CH}_{3} \mathrm{CN}\right]>300 \mathrm{pptv}$;

$3\left[\mathrm{CH}_{3} \mathrm{CN}\right]>150 \mathrm{pptv}$;

${ }^{4} \Delta \mathrm{O}_{3} / \Delta \mathrm{CO}<2 \mathrm{ppbv}^{\mathrm{ppbv}}{ }^{-1}$.

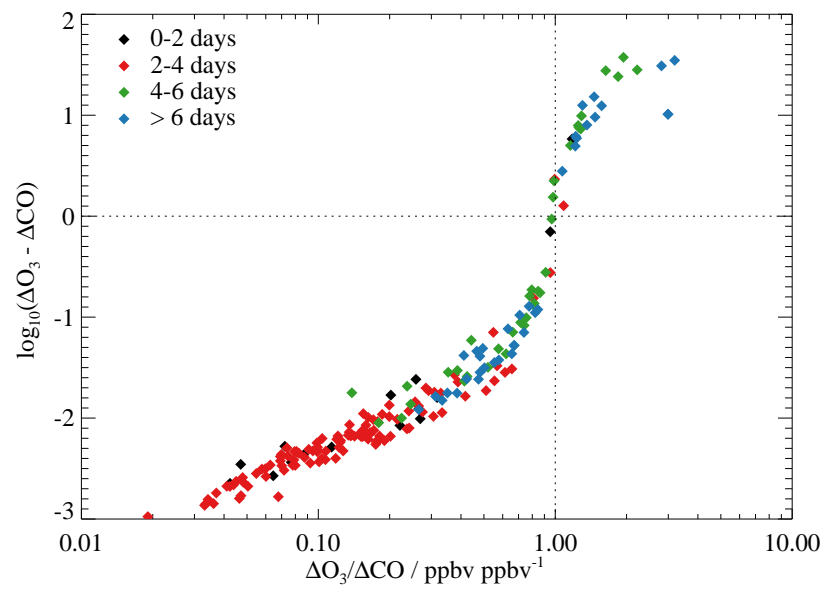

Fig. 7. Scatter plot of $\log _{10}$ of the difference between $\mathrm{O}_{3}$ and $\mathrm{CO}$ enhancements in biomass burning plumes relative to background values (i.e. $\Delta \mathrm{O}_{3}$ and $\Delta \mathrm{CO}$ ) as a function of the $\Delta \mathrm{O}_{3} / \Delta \mathrm{CO}$ enhancement ratio. The data are filtered based on photochemical ages calculated from the $\ln \left(\mathrm{C}_{3} \mathrm{H}_{8} / \mathrm{C}_{2} \mathrm{H}_{6}\right)$ ratio. The horizontal and vertical dotted lines show the zero difference and unit ratio values, respectively.

0.015 and $0.05 \mathrm{ppbv} \mathrm{ppbv}^{-1}$ over a range of photochemical ages between 0 and 8 days. The $\Delta \mathrm{O}_{3} / \Delta \mathrm{CO}$ ratio decreases from 0.03 to $0.01 \mathrm{ppbv} \mathrm{ppbv}^{-1}$ between 0 and 2 days of photochemical ageing, with the lowest values associated with higher $\mathrm{CO}$ mixing ratios in excess of $250 \mathrm{ppbv}$, increasing from approximately $150 \mathrm{ppbv}$ (Fig. 6b), and increases from 0.03 to $0.05 \mathrm{ppbv} p p b v^{-1}$ between 5 and 8 days of photochemical ageing. The high $\mathrm{CH}_{3} \mathrm{CN}$ measurements show a wide range of $\Delta \mathrm{O}_{3} / \Delta \mathrm{CO}$ ratios, from 0.02 to $0.3 \mathrm{ppbv} \mathrm{ppbv}^{-1}$, between 2 and 4 days of photochemical ageing. A few high $\mathrm{CH}_{3} \mathrm{CN}$ measurements with photochemical ages between 4 and 8 days have higher $\Delta \mathrm{O}_{3} / \Delta C O$ ratios from 0.2 to $0.5 \mathrm{ppbvppv}^{-1}$. In general, the moderate $\mathrm{CH}_{3} \mathrm{CN}$ measurements have photochemical ages greater than 4 days and exhibit higher $\Delta \mathrm{O}_{3} / \Delta \mathrm{CO}$ ratios between
0.1 and $1.0 \mathrm{ppbv} \mathrm{ppbv}^{-1}$. Some measurements with moderate $\mathrm{CH}_{3} \mathrm{CN}$ have photochemical ages less than 4 days, although this does not appear to significantly affect the $\Delta \mathrm{O}_{3} / \Delta \mathrm{CO}$ ratio in these air masses. The measurements made with less than 2 days photochemical ageing and $\Delta \mathrm{O}_{3} / \Delta C O$ ratios greater than $0.07 \mathrm{ppbv} \mathrm{ppbv}^{-1}$ may be attributable to a fire source with different initial NMHC mixing ratios than those used in the photochemical age calculation or could be aged air masses that have experienced mixing with air of different origin which has influenced the NMHC abundance. Further analysis of these data points is beyond the scope of the analysis presented here.

Figure 7 shows that the main contributing factor to the variability in the $\Delta \mathrm{O}_{3} / \Delta C \mathrm{C}$ ratios observed in biomass burning plumes changes as a function of the plume photochemical age. As reflected in Fig. $4 \mathrm{a}$ and $\mathrm{b}$, variability in $\Delta \mathrm{O}_{3}$ increases as a function of $\Delta \mathrm{O}_{3} / \Delta \mathrm{CO}$ while variability in $\Delta \mathrm{CO}$ decreases to a point where the main contributing factor changes from $\Delta \mathrm{CO}$ to $\Delta \mathrm{O}_{3}$. For air masses with photochemical ages of less than 4 days, $\Delta \mathrm{O}_{3}$ is generally less than $\Delta \mathrm{CO}$ (i.e. $\log _{10}\left(\Delta \mathrm{O}_{3}-\Delta \mathrm{CO}\right)<0$ and $\left.\Delta \mathrm{O}_{3} / \Delta \mathrm{CO}<1\right)$ and the variability in $\Delta \mathrm{O}_{3} / \Delta \mathrm{CO}$ is controlled by $\Delta \mathrm{CO}$. At photochemical ages greater than 4 days, the variability in $\Delta \mathrm{O}_{3} / \Delta \mathrm{CO}$ is controlled by a combination of $\Delta \mathrm{CO}$, for $\Delta \mathrm{O}_{3} / \Delta \mathrm{CO}$ between 0.1 and 1.0, and $\Delta \mathrm{O}_{3}$, for $\Delta \mathrm{O}_{3} / \Delta \mathrm{CO}$ greater than 1.0.

A review of $\mathrm{O}_{3}$ production in the outflow from wildfires, including boreal regions, was recently presented by Jaffe and Wigder (2012). Table 2 presents statistics of $\Delta \mathrm{O}_{3} / \Delta \mathrm{CO}$ ratios in boreal biomass burning plumes sampled during BORTAS, arranged by photochemical age following Jaffe and Wigder (2012). The BORTAS results show that the $\Delta \mathrm{O}_{3} / \Delta \mathrm{CO}$ ratio increases with plume age in both the range and average (mean and median) values, indicating that $\mathrm{O}_{3}$ production is enhanced in plumes that have undergone more photochemical processing as they are transported away from the source region. For plume ages less than 2 days, the BORTAS $\Delta \mathrm{O}_{3} / \Delta C \mathrm{C}$ ratios are within the range of ARCTAS measurements for the same category (Alvarado et al., 2010) and the mean BORTAS value of $0.020 \pm 0.008 \mathrm{ppbv}_{\mathrm{ppbv}}{ }^{-1}$ 
is comparable to the mean of $0.018 \mathrm{ppbv} p p b v^{-1}$ calculated by Jaffe and Wigder (2012) from studies by Alvarado et al. (2010), Goode et al. (2000), Singh et al. (2010) and DeBell et al. (2004). For plume ages between 2 and 5 days the range of BORTAS $\Delta \mathrm{O}_{3} / \Delta \mathrm{CO}$ ratios are comparable to the ranges determined for boreal biomass burning plumes from eastern Canada (Mauzerall et al., 1996) and Siberia (Tanimoto et al., 2008). The mean ratio of $0.13 \pm 0.10 \mathrm{ppbv} \mathrm{ppbv}^{-1}$ for the high $\mathrm{CH}_{3} \mathrm{CN}$ measurements is comparable to the average ratio of $0.15 \mathrm{ppbv} \mathrm{ppvv}^{-1}$ calculated by Jaffe and Wigder (2012) for this plume category. For the moderate $\mathrm{CH}_{3} \mathrm{CN}$ measurements the mean ratio increases to $0.27 \pm 0.31 \mathrm{ppbv} \mathrm{ppbv}^{-1}$, which is also comparable to the mean, although with a much wider range of values (ratio reported by (Jaffe and Wigder, 2012)). For plume ages greater than 5 days, the BORTAS $\Delta \mathrm{O}_{3} / \Delta \mathrm{CO}$ ratios are typically within the range of values presented by Jaffe and Wigder (2012). The mean $\Delta \mathrm{O}_{3} / \Delta \mathrm{CO}$ ratio of $0.81 \pm 0.52 \mathrm{ppbv} \mathrm{ppbv}^{-1}$ for BORTAS is higher than the mean values of approximately $0.25 \mathrm{ppbv} \mathrm{ppbv}^{-1}$ for North American boreal biomass burning plumes (Pfister et al., 2006; Val Martin et al., 2006) and is more comparable to similarly aged plumes originating in Siberia (Bertschi and Jaffe, 2005; Honrath et al., 2004). The observed upperlimit of $2.55 \mathrm{ppbv} \mathrm{ppbv}^{-1}$ in the range of $\Delta \mathrm{O}_{3} / \Delta \mathrm{CO}$ ratios for these measurements is much higher than for the data presented by Jaffe and Wigder (2012). Restricting this upper-limit to $2 \mathrm{ppbv}$ removes two data points from the BORTAS statistics, reducing the mean value from $0.81 \pm 0.57 \mathrm{ppbv} \mathrm{ppbv}^{-1}$ to $0.75 \pm 0.41 \mathrm{ppbv} \mathrm{ppbv}^{-1}$. The observed increase in $\Delta \mathrm{O}_{3} / \Delta \mathrm{CO}$ ratios calculated from the BORTAS plume measurements with longer photochemical ages and moderate $\mathrm{CH}_{3} \mathrm{CN}$ reflects plume dilution and efficient $\mathrm{O}_{3}$ production at low $\mathrm{NO}_{\mathrm{x}}$ mixing ratios (Bertschi and Jaffe, 2005; Jaffe and Wigder, 2012).

\section{3 $\mathrm{O}_{3}$ photochemistry in boreal biomass burning outflow}

The $\Delta \mathrm{O}_{3} / \Delta \mathrm{CO}$ ratios presented above assume that enhancements in plume air over background values provide an indication of $\mathrm{O}_{3}$ production in biomass burning plumes and that variations in the $\Delta \mathrm{O}_{3} / \Delta \mathrm{CO}$ ratio are due to variability in $\Delta \mathrm{O}_{3}$. However, this ratio provides limited information on the photochemistry occurring in the plume air masses. We now evaluate $\mathrm{O}_{3}$ mixing ratios measured in boreal biomass burning plumes during the BORTAS campaign against measurements of other chemical species associated with $\mathrm{O}_{3}$ photochemistry.

\subsubsection{Ozone production efficiency}

A useful concept for understanding $\mathrm{O}_{3}$ formation in polluted air masses is the ozone production efficiency (OPE) which is defined as the number of $\mathrm{O}_{3}$ molecules produced per molecule of $\mathrm{NO}_{\mathrm{x}}$ that is oxidised (e.g. Trainer et al., 1993; Olszyna et al., 1994; Ryerson et al., 1998). We evaluate OPE in the plumes sampled during the BORTAS campaign through comparison of the measured $\mathrm{O}_{3}$ mixing ratios to measurements of alkyl nitrates and the surrogate species $\mathrm{NO}_{\mathrm{z}}$. Photochemical production of $\mathrm{O}_{3}$ in polluted air masses is dependent on the interaction between VOC and $\mathrm{NO}_{\mathrm{x}}$ chemistry as shown in Fig. 1 and Reactions (R4)(R6)/(R7). Thus, comparing the products of Reactions (R6) and (R7) provides an indication of the potential for $\mathrm{O}_{3}$ formation in an air mass based on the relative concentrations of alkyl nitrates $\left(\mathrm{RONO}_{2}\right.$ in Reactions (R6) and (R7) and referred to as $\Sigma$ AN from hereon in) and the level of oxidant $\left(\mathrm{O}_{\mathrm{x}}=\mathrm{O}_{3}+\mathrm{NO}_{2}\right)$. Similarly, the surrogate species $\mathrm{NO}_{\mathrm{z}}$ $\left(=\mathrm{NO}_{\mathrm{y}}-\mathrm{NO}_{\mathrm{x}}\right)$ represents the photo-oxidation products of reactive nitrogen species (i.e. $\mathrm{NO}_{\mathrm{x}}$ ) and evaluating $\mathrm{O}_{\mathrm{x}}$ in relation to $\mathrm{NO}_{\mathrm{Z}}$ will provide an indication of the potential for $\mathrm{O}_{3}$ formation in an air mass.

Figures $8 \mathrm{a}$ and $\mathrm{b}$ show the distribution of $\mathrm{O}_{\mathrm{x}}$ relative to $\Sigma \mathrm{AN}$ and $\mathrm{NO}_{\mathrm{z}}$ measured in boreal biomass burning plumes during BORTAS, respectively. In both cases three main populations of data points can be clearly defined with a distinctive "L-shape" distribution for measurements made on all BORTAS research flights, not including flight B626 (i.e., $\mathrm{O}_{\mathrm{x}}$ mixing ratios in excess of $30 \mathrm{ppbv}$ ). Higher values of $\Sigma \mathrm{AN}$ and $\mathrm{NO}_{\mathrm{z}}$ generally correspond to lower values of $\mathrm{O}_{\mathrm{x}}$, and lower values of $\Sigma \mathrm{AN}$ and $\mathrm{NO}_{\mathrm{z}}$ generally correspond to higher values of $\mathrm{O}_{\mathrm{x}}$. The main factor that distinguishes between the two branches of the "L-shape" pattern is the aerosol loading of the measured air mass. High aerosol loading in the plumes is determined using measured black carbon mass concentration greater than $0.1 \mathrm{\mu g} \mathrm{cm}^{-3}$ and nephelometer measurements of the total scatter coefficient at $550 \mathrm{~nm}$ greater than $1.1 \times 10^{-5} \mathrm{~m}^{-1}$ (corresponding to a black carbon mass concentration of $0.1 \mu \mathrm{g} \mathrm{cm}^{-3}$, and used to fill in gaps in the black carbon measurements). Although the vast majority of scattering is due to nonrefractory aerosols, the black carbon mass concentration and total scatter coefficient measurements are strongly correlated $(r=0.92)$ in the biomass burning plumes sampled during BORTAS, suggesting that these are reliable indicators of plume aerosol loading. The highest mixing ratios of $\Sigma \mathrm{AN}$ ( $>0.5 \mathrm{ppbv}$ ) and $\mathrm{NO}_{\mathrm{z}}(>2 \mathrm{ppbv})$ were measured at night-time and daytime, respectively, in air masses with high aerosol loading and corresponding $\mathrm{O}_{\mathrm{x}}$ mixing ratios between approximately 40 and 60 ppbv. Daytime $\Sigma \mathrm{AN}$ and night-time $\mathrm{NO}_{\mathrm{z}}$ measurements along the horizontal branch of the "L-shape" distribution were typically made in air masses with high aerosol loading with mixing ratios ranging between $0-0.5$ and 0-2 ppbv, respectively. Measurements made in plume air masses with low aerosol loading (black carbon mass concentration; $0.1 \mu \mathrm{g} \mathrm{cm}^{-3}$ ) lie along the vertical branch of the "L-shaped" distributions in Fig. 8 and generally have lower $\Sigma$ AN $(<0.2$ ppbv $)$ and $\mathrm{NO}_{\mathrm{z}}(<0.8 \mathrm{ppbv})$ mixing ratios and a wider range of $\mathrm{O}_{\mathrm{x}}$ mixing ratios between 40 and 90 ppbv. 
(a)

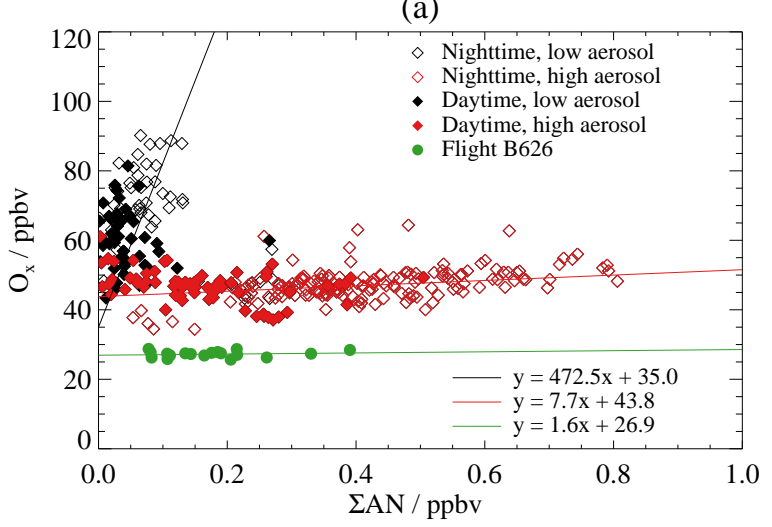

(b)

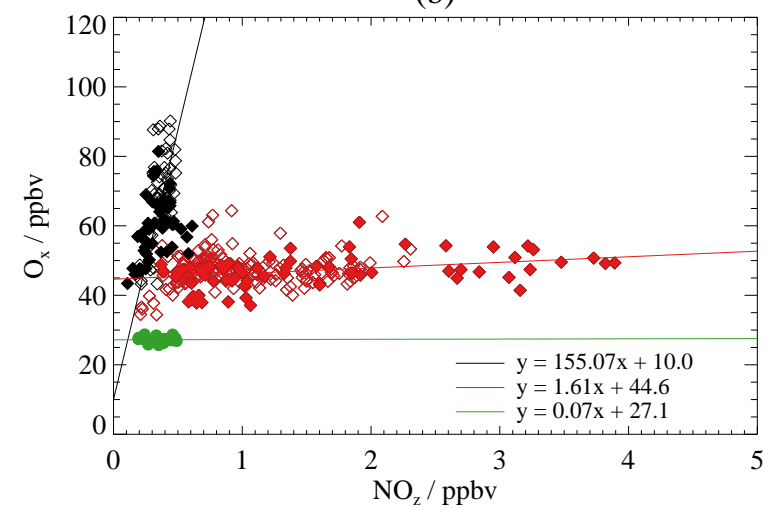

Fig. 8. Relationship between (a) $\mathrm{O}_{\mathrm{x}}\left(\mathrm{O}_{3}+\mathrm{NO}_{2}\right)$ and alkyl nitrates $(\Sigma \mathrm{AN})$, and (b) $\mathrm{O}_{\mathrm{x}}$ and $\mathrm{NO}_{\mathrm{z}}\left(\mathrm{NO}_{\mathrm{y}}-\mathrm{NO}_{\mathrm{x}}\right)$ measured in boreal biomass burning plumes from the BAe-146 over the course of the BORTAS measurement campaign. Night-time and daytime measurements are represented by open and closed diamonds, respectively. Black symbols represent measurement with black carbon mass concentrations less than $0.1 \mathrm{\mu g} \mathrm{cm}^{-3}$ and red symbols with black carbon mass concentrations greater than $0.1 \mu \mathrm{g} \mathrm{cm}^{-3}$. Measurements made on flight B626 over the fire region in Northwestern Ontario are treated separately and are represented by closed green circles.

It should be noted that measurements with lower $\mathrm{O}_{\mathrm{x}}$ mixing ratios (40-60 ppbv) show a mixture of both high and low aerosol loading and $\mathrm{O}_{\mathrm{x}}$ mixing ratios greater than $60 \mathrm{ppbv}$ were made only in air masses with low aerosol loading. The third population of data points, with $\mathrm{O}_{\mathrm{x}}$ mixing ratios less than $30 \mathrm{ppbv}$ corresponds to measurements made during flight B626 over Northwestern Ontario and show a narrower range of $\mathrm{O}_{\mathrm{x}}(25-30 \mathrm{ppbv})$ for $\Sigma \mathrm{AN}$ between 0.05 and $0.4 \mathrm{ppbv}$ and $\mathrm{NO}_{\mathrm{z}}$ between 0.1 and $0.5 \mathrm{ppbv}$.

We estimate OPE in biomass burning plumes relative to $\Sigma \mathrm{AN}$ and $\mathrm{NO}_{\mathrm{z}}$ from the gradients of straight lines fitted to each population of data points in Fig. 8 using a nonlinear least squares method. This is a useful diagnostic for giving a general indication of the potential for $\mathrm{O}_{3}$ formation but it should be noted that calculating OPE in this way represents an upper limit due to potential loss of $\mathrm{O}_{\mathrm{x}}$ and $\mathrm{NO}_{\mathrm{y}}$ species from the plume air due to wet and dry deposition (e.g. Wang et al., 1996; Rickard et al., 2002). For relatively fresh biomass burning plumes measured on flight B626 the slope of the fit is $1.6 \pm 15.6 \mathrm{ppbv} \mathrm{ppbv}^{-1}$ relative to $\Sigma \mathrm{AN}$ and $0.07 \pm 13.5 \mathrm{ppbv} p p b v^{-1}$ relative to $\mathrm{NO}_{\mathrm{z}}$ (i.e., $1.6 \mathrm{O}_{\mathrm{x}}$ molecules are produced relative to each molecule of $\Sigma \mathrm{AN}$ and $0.07 \mathrm{O}_{\mathrm{x}}$ molecules per molecule of $\mathrm{NO}_{\mathrm{z}}$ ). The gradient of the fit increases to $7.7 \pm 3.5 \mathrm{ppbv} \mathrm{ppbv}^{-1}$ relative to $\Sigma \mathrm{AN}$ and $1.6 \pm 0.9 \mathrm{ppbvppv}^{-1}$ relative to $\mathrm{NO}_{\mathrm{z}}$ for the plume measurements made with high aerosol loading and to $472 \pm 28 \mathrm{ppbvppv}^{-1}$ relative to $\Sigma \mathrm{AN}$ and $155 \pm 5 \mathrm{ppbv} \mathrm{ppbv}^{-1}$ relative to $\mathrm{NO}_{\mathrm{z}}$ for the plume measurements made with low aerosol loading. The change in the relationship between $\mathrm{O}_{\mathrm{x}}$ and $\Sigma \mathrm{AN}$ with plume photochemical age observed during BORTAS is consistent with that observed in pollution outflow from Mexico City by Perring et al. (2010) in which slopes of the lines of best fit to aircraft measurements in the outflow increased from approximately $16 \mathrm{ppbv} \mathrm{ppbv}^{-1}$ to $89 \mathrm{ppbv} \mathrm{ppbv}^{-1}$ as the plume age increased from less than $10 \mathrm{~h}$ to between 40 and $50 \mathrm{~h}$. Perring et al. (2010) explained that increased $\mathrm{O}_{3}$ production with plume age was due to an increase in non-nitrate producing $\mathrm{O}_{3}$ precursors associated with depleted primary VOCs and enhanced secondary OVOCs. The high OPE relative to $\Sigma$ AN calculated from the BORTAS measurements of aged plumes with low aerosol loading are consistent with slopes for remote areas of the troposphere such as the remote $\mathrm{Pa}$ cific (Perring et al., 2010). The OPE values relative to $\mathrm{NO}_{\mathrm{z}}$ calculated from the BORTAS measurements represent the extremes of typical OPE values previously reported in the literature and summarised in Table 1 of Rickard et al. (2002). The OPE of $1.6 \mathrm{ppbv} p p b v^{-1}$ relative to $\mathrm{NO}_{\mathrm{z}}$ in the BORTAS plume measurements with high aerosol loading is similar to the OPE observed in urban and power station pollution plumes in the eastern USA (Chin et al., 1994; Ryerson et al., 1998; Daum et al., 2000; Sillman, 2000) whereas the OPE of $155 \mathrm{ppbv} \mathrm{ppv}^{-1}$ in the plume measurements with low aerosol loading is more comparable to the OPE observed in aged air masses of continental origin over the western Pacific Ocean (Davis et al., 1996).

An alternative method for calculating OPE from the observed $\mathrm{O}_{\mathrm{x}}$ and $\mathrm{NO}_{\mathrm{z}}$ mixing ratios is to calculate enhancements of each observed value relative to a background value (i.e. $\mathrm{OPE}=\Delta \mathrm{O}_{\mathrm{x}} / \Delta \mathrm{NO}_{\mathrm{z}}$ ) similar to the method described for $\Delta \mathrm{O}_{3} / \Delta \mathrm{CO}$ in the previous section. Figure 9 shows the distribution of OPE using $\Delta \mathrm{O}_{\mathrm{x}} / \Delta \mathrm{NO}_{\mathrm{z}}$ ratios calculated from the BORTAS biomass burning plume measurements as a function of $\mathrm{NO}_{\mathrm{x}}$. Background mixing ratios of $\mathrm{O}_{\mathrm{x}}$ and $\mathrm{NO}_{\mathrm{z}}$ were determined, in the same way as the background $\mathrm{O}_{3}$ and $\mathrm{CO}$ values described in the previous section, to be $30 \mathrm{ppbv}$ and $0.1 \mathrm{ppbv}$, respectively. The measurements are filtered for daytime/night-time and high/low aerosol loading as in Fig. 8. Measurements made in plume air with high aerosol loading typically have OPE less than $70 \mathrm{ppbv} \mathrm{ppbv}^{-1}$ with 


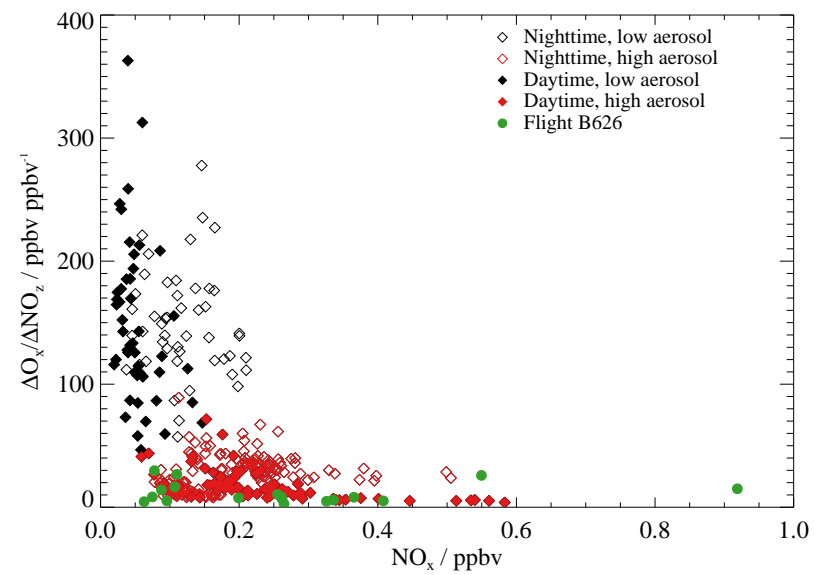

Fig. 9. Relationship between the enhancement ratio of $\mathrm{O}_{\mathrm{x}}$ to $\mathrm{NO}_{\mathrm{Z}}$ $\left(\Delta \mathrm{O}_{\mathrm{X}} / \Delta \mathrm{NO}_{\mathrm{Z}}\right)$ in units of ppbv ppbv ${ }^{-1}$ and $\mathrm{NO}_{\mathrm{X}}$ mixing ratio in units of ppbv measured in boreal biomass burning plumes from the BAe-146 over the course of the BORTAS measurement campaign. Symbols are the same as those described for Fig. 8.

$\mathrm{NO}_{\mathrm{x}}$ mixing ratios ranging from 0.05 and $0.6 \mathrm{ppbv}$. Measurements with low aerosol loading have higher OPE between 50 and $400 \mathrm{ppbv} \mathrm{ppbv}^{-1}$ and a narrower range of $\mathrm{NO}_{\mathrm{x}}$ mixing ratios between 0 and $0.25 \mathrm{ppbv}$. The $\mathrm{NO}_{\mathrm{x}}$ mixing ratios in this branch of the distribution shows a clear distinction between higher $(>0.1 \mathrm{ppbv})$ and lower $(<0.1 \mathrm{ppbv})$ $\mathrm{NO}_{\mathrm{x}}$ mixing ratios with higher values corresponding to the night-time measurements. The measurements made on flight B626 over Northwestern Ontario have low OPE less than $30 \mathrm{ppbv} \mathrm{ppbv}^{-1}$ over a similar range of $\mathrm{NO}_{\mathrm{x}}$ mixing ratios as the high aerosol measurements. The changes in OPE relative to $\mathrm{NO}_{\mathrm{x}}$ for the two populations of data points defined by the aerosol loading indicates that plume measurements were potentially made under two different chemical regimes. For the measurements made on flight B626 and those made during daytime with high aerosol loading, the large range of $\mathrm{NO}_{\mathrm{x}}$ mixing ratios and small change in OPE possibly indicate of a more VOC-limited regime. For the low aerosol loading measurements, the much narrower range of $\mathrm{NO}_{\mathrm{x}}$ mixing ratio and larger change in OPE possibly indicating a more $\mathrm{NO}_{\mathrm{x}}$-limited regime.

Figure 10 shows the distributions of relative humidity (RH) and aircraft altitude relative to OPE partitioned for night-time/daytime and high/low aerosol loading, as described above. Figure 10a shows that the measurements made with OPE less than $70 \mathrm{ppbvpbv}^{-1}$ are typically characterised by higher relative humidity $(>40 \%)$ than the measurements with OPE greater than $70 \mathrm{ppbv} \mathrm{ppbv}^{-1}$ (RH typically $<40 \%$ ). The relationship between RH and OPE shows no distinction between daytime and night-time measurements. Figure 10b shows the vertical distribution of RH measured in boreal biomass burning plumes throughout the campaign. In general, measurements with low aerosol loading

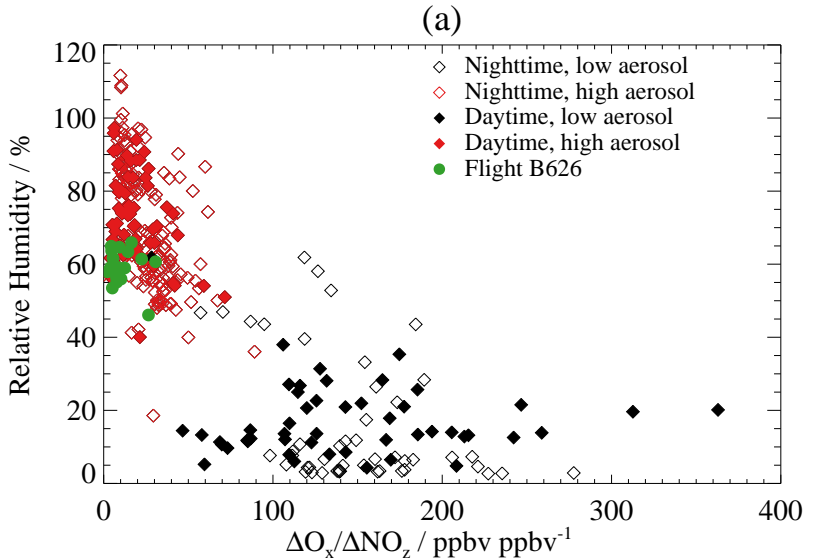

(b)

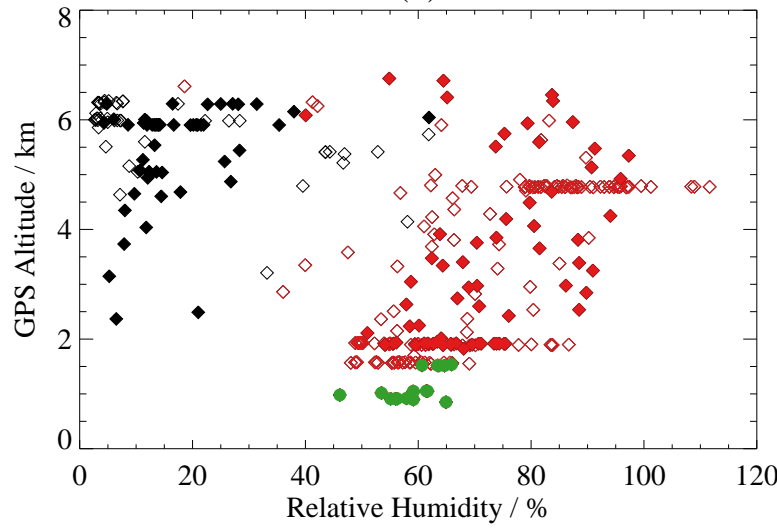

Fig. 10. Relationship between (a) relative humidity in percent and the ratio of the $\Delta \mathrm{O}_{\mathrm{X}} / \Delta \mathrm{NO}_{\mathrm{Z}}$ ratio in units of ppbv ppbv ${ }^{-1}$, and (b) relative humidity and aircraft GPS altitude in $\mathrm{km}$ measured in boreal biomass burning plumes over the course of the BORTAS measurement campaign. Symbols are the same as those described for Fig. 8 .

and low RH were made at higher altitudes $(>3 \mathrm{~km})$ during both daytime and night-time. Interestingly, measurements with high aerosol loading and high RH but low OPE were not solely made at lower altitudes but across the entire vertical range of the measurements, from 0.5 to $7 \mathrm{~km}$. In general, plume measurements with low aerosol loading and low $\mathrm{RH}$ had corresponding $\mathrm{CO}, \mathrm{CH}_{3} \mathrm{CN}$ and $\mathrm{VOC}$ mixing ratios significantly higher than their respective background values. This, in combination with relatively long photochemical lifetimes of some of these species (approximately 40 days for $\mathrm{CO}$ and longer lived VOCs such as $\mathrm{C}_{2} \mathrm{H}_{6}$ ), suggests that photochemistry drives the increased OPE in these plumes. Low aerosol loading and low RH may be explained by these more aged air masses having experienced precipitation events during transport from the emission source region. Analysis of ground-based remote sensing measurements made from Halifax, NS, during the BORTAS campaign period identified a biomass burning plume with relatively low fine mode aerosol optical depth correlated with enhanced CO total columns, 
which was attributable to precipitation along the plume trajectory (Griffin et al., 2013; Franklin et al., 2013).

The aerosol loading of the measured air masses provides the distinction between the two branches of the "L-shaped" pattern in OPE relative to both $\Sigma \mathrm{AN}$ and $\mathrm{NO}_{\mathrm{z}}$. Suppressed $\mathrm{O}_{3}$ formation in biomass burning plume air masses with high aerosol loading is perhaps not so unexpected, as increased aerosol optical depth would be expected to attenuate the actinic flux and photolysis of $\mathrm{NO}_{2}$ to form $\mathrm{O}_{3}$. However, this may not completely account for the suppressed $\mathrm{O}_{3}$ formation as recent laboratory studies have highlighted potential loss of $\mathrm{O}_{3}$ and $\mathrm{NO}_{\mathrm{y}}$ species through heterogeneous uptake by aerosol in biomass burning plumes (Longfellow et al., 2000; Grassian, 2001). Furthermore, light-induced heterogeneous photochemical $\mathrm{O}_{3}$ loss on the surface of biomass burning aerosols that increases with relative humidity has also been observed in laboratory and field measurements and shown to influence regional tropospheric $\mathrm{O}_{3}$ distributions (Konovalov et al., 2012). Figure 11 shows an example of the relative change in $\mathrm{NO}_{2}$ photolysis rate, $j_{\mathrm{NO}_{2}}$, measured from the BAe-146 in plume and non-plume air masses along a section of BORTAS flight B624 over the North Atlantic Ocean on 21 July 2011 (see Table 1 and Fig. 9 in Palmer et al., 2013). This flight made five interceptions of a biomass burning plume with significantly elevated $\mathrm{CO}, \mathrm{CH}_{3} \mathrm{CN}$ and black carbon at altitudes between 1.7 and $3.2 \mathrm{~km}$, and provides a useful dataset for evaluating the potential impact of enhanced black carbon aerosol on $j_{\mathrm{NO}_{2}}$ in biomass burning smoke plumes. These measurements were made above a planetary boundary layer between approximately 0.5 and $1.5 \mathrm{~km}$ estimated from temperature profiles over Sable Island and wind profiler measurements near Halifax (not shown). During the first two interceptions - prior to approximately 202.75 day and at 202.77 day of 2011 - the $j_{\mathrm{NO}_{2}}$ measurements show no clear deviation from the non-plume measurements. On the final three interceptions, at approximately 202.80, 202.85 and 202.89 days of the same year, the photolysis rate is reduced by a factor of approximately 2 relative to the rate measured in clear air. Although $\mathrm{j}_{\mathrm{NO}_{2}}$ shows a reduction in the plume measurements, it is not reduced completely to zero, which potentially indicates that the reduced OPE in these measurements could be due to combination of the processes outlined above. Detailed analysis of these processes, which requires numerical model calculations to quantify the change in $j_{\mathrm{NO}_{2}}$ and its influence on $\mathrm{O}_{3}$ photochemistry, is beyond the scope of the analysis presented here, and will be investigated through model studies that will be the subject of future papers.

\subsubsection{Photostationary steady state and instantaneous $\mathrm{O}_{3}$ production}

To further evaluate $\mathrm{O}_{3}$ photochemistry in the biomass burning plumes sampled during the BORTAS campaign we use a photostationary steady state calculation to quantify the relative contributions of $\mathrm{NO}_{\mathrm{x}}$ and other peroxy radicals to the $\mathrm{O}_{3}$ (a)

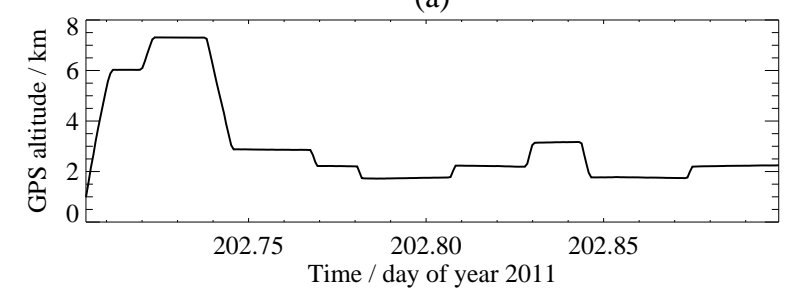

(b)

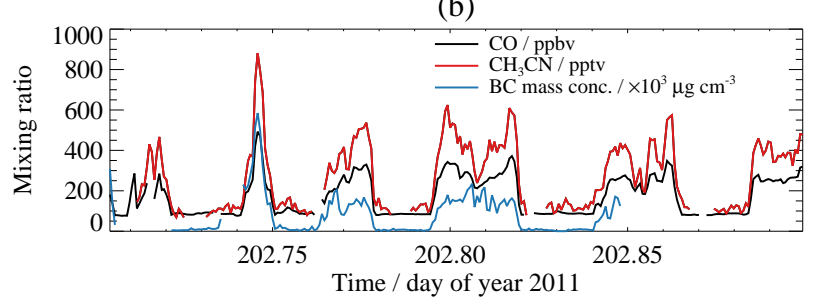

(c)

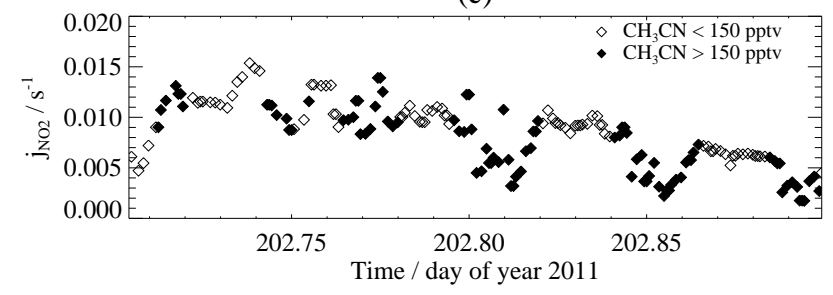

Fig. 11. Section of BORTAS flight B624 on 21 July 2011 showing (a) aircraft GPS altitude in km; (b) mixing ratios $\mathrm{CO}$ in ppbv and $\mathrm{CH}_{3} \mathrm{CN}$ in pptv and black carbon mass concentration in units of $10^{3} \mu \mathrm{g} \mathrm{cm}^{-3}$; and (c) $\mathrm{NO}_{2}$ photolysis rate, $j_{\mathrm{NO}_{2}}$, in units of s${ }^{-1}$. Solid symbols in (c) indicate measurements of $\mathrm{CH}_{3} \mathrm{CN}$ mixing ratios greater than $150 \mathrm{pptv}$ to indicate plume measurements.

production efficiency. From Reactions (R2) and (R3) and assuming photostationary steady state (i.e. the loss of $\mathrm{O}_{3}$ via Reaction (R2) is equal to the production of $\mathrm{O}_{3}$ via Reaction (R3)), the following ratio can be defined:

$\Phi=\frac{j_{\mathrm{NO}_{2}}\left[\mathrm{NO}_{2}\right]}{k_{\mathrm{NO}+\mathrm{O}_{3}}[\mathrm{NO}]\left[\mathrm{O}_{3}\right]}$

where $\Phi$ is known as the photostationary ratio, $[\mathrm{X}]$ represents the concentration of species $\mathrm{X}, j_{\mathrm{NO}_{2}}$ is the photolysis rate of $\mathrm{NO}_{2}$ in units of $\mathrm{s}^{-1}$, and $k_{\mathrm{NO}+\mathrm{O} 3}$ is the kinetic rate coefficient for the reaction between $\mathrm{NO}$ and $\mathrm{O}_{3}$ in units of molecules $\mathrm{cm}^{-3} \mathrm{~s}^{-1}$. The value of $k_{\mathrm{NO}+\mathrm{O} 3}$ was calculated along the aircraft flight track using the recommended IUPAC definition of $1.4 \times 10^{-12} \exp (-1310 / T)$ (Atkinson et al., 2004) where $T$ is the air temperature measured from the aircraft. The photostationary ratio would have a value of unity if chemical cycling between $\mathrm{O}_{3}$ and $\mathrm{NO}_{\mathrm{x}}$ was the only process occurring (Leighton, 1961; Cantrell et al., 2003; Griffin et al., 2007). Deviations of this ratio from unity therefore give an indication of the influence of other chemical processes, for example, interaction between $\mathrm{NO}$ and families of organic peroxy radicals $\left(\mathrm{RO}_{\mathrm{x}}\right)$ and hydro peroxy radicals $\left(\mathrm{HO}_{\mathrm{x}}\right)$; we 
(a)

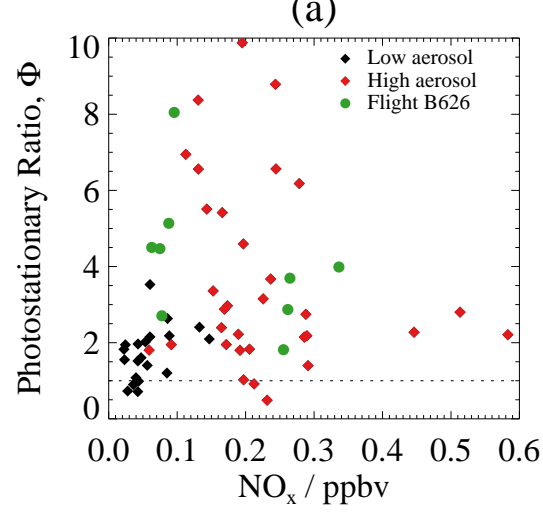

(c)

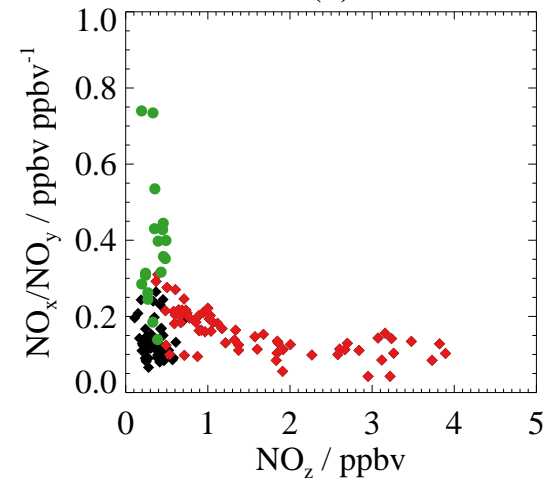

(b)

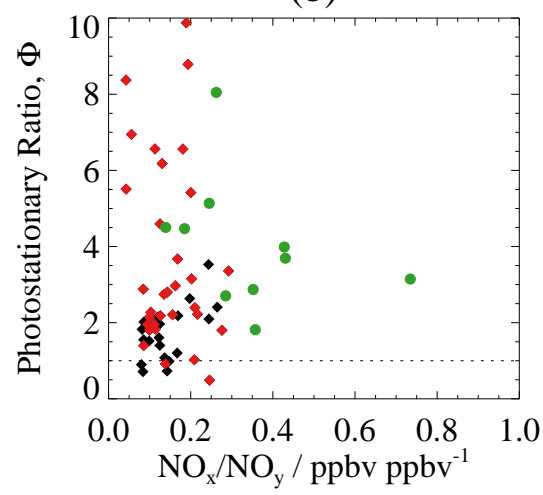

(d)

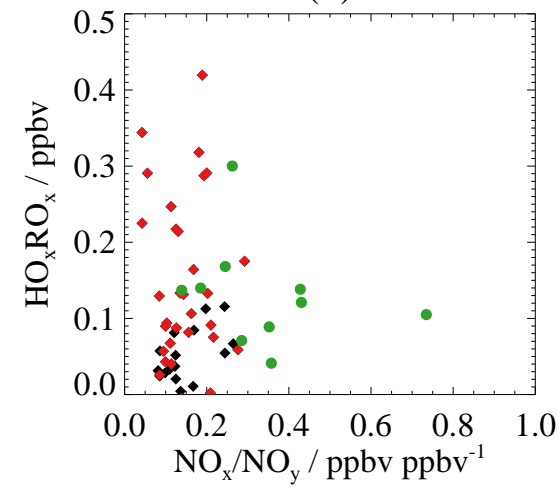

Fig. 12. Relationship between $\mathrm{O}_{3}$ photostationary state and the $\mathrm{NO}_{\mathrm{y}}$ budget measured in boreal biomass burning plumes over the course of the BORTAS campaign. (a) and (b) show the calculated photostationary ratio, $\Phi$, versus $\mathrm{NO}_{\mathrm{x}}$ mixing ratios (ppbv) and the ratio of $\mathrm{NO}_{\mathrm{x}}$ to $\mathrm{NO}_{\mathrm{y}}$ respectively. (c) shows the relationship between $\mathrm{NO}_{\mathrm{x}} / \mathrm{NO}_{\mathrm{y}}$ and $\mathrm{NO}_{\mathrm{z}}$. (d) shows calculated total peroxy radical mixing ratios, $\mathrm{HO}_{\mathrm{x}} \mathrm{RO}_{\mathrm{x}}$, required for a photostationary ratio of unity versus $\mathrm{NO}_{\mathrm{x}}$ mixing ratio. Symbols are the same as those described for Fig. 4.

generalise these families of peroxy radicals as $\mathrm{HO}_{\mathrm{x}} \mathrm{RO}_{\mathrm{x}}$ following Cantrell et al. (2003).

Figure 12 shows plots of photostationary steady state calculations made with the BORTAS aircraft measurements in biomass burning plumes over the course of the campaign. The photostationary ratio defined above is calculated from the measured values of each parameter in Eq.( 1). Figure 12a shows the photostationary ratio versus $\mathrm{NO}_{\mathrm{x}}$ mixing ratio with symbols denoting measurements made with high/low aerosol, as defined above. The calculated ratios for all the plume data points show a wide range of values between 0 and 10. Ratios for the measurements made with low aerosol loading generally lie in a narrower range from 0 to 2 , suggesting that the measurements are closer to photostationary steady state. The measurements made with high aerosol generally have photostationary ratios greater than 2 with a wide range of values extending as high as 10 . Figure $12 \mathrm{~b}$ also shows the calculated photostationary ratio but as a function of the ratio $\mathrm{NO}_{\mathrm{x}} / \mathrm{NO}_{\mathrm{y}}$. Note that the expression defining $\mathrm{NO}_{z}$ (i.e. $\mathrm{NO}_{z}=\mathrm{NO}_{\mathrm{y}}-\mathrm{NO}_{\mathrm{x}}$ ) can be rewritten as $\mathrm{NO}_{z}=$ $\mathrm{NO}_{\mathrm{y}}\left(1-\mathrm{NO}_{\mathrm{x}} / \mathrm{NO}_{\mathrm{y}}\right)$, in which the term $1-\left(\mathrm{NO}_{\mathrm{x}} / \mathrm{NO}_{\mathrm{y}}\right)$ can be considered as a measure of the photochemical age of the air mass (i.e. the fraction of the initial $\mathrm{NO}_{\mathrm{x}}$ emitted that has been converted into photooxidation products, as $\mathrm{NO}_{\mathrm{y}}$ represents total $\mathrm{NO}_{\mathrm{x}}$ emissions) (Olszyna et al., 1994). Values of $\mathrm{NO}_{\mathrm{x}} / \mathrm{NO}_{\mathrm{y}}$ closer to unity are therefore representative of fresher emissions because there has been less photochemical processing of $\mathrm{NO}_{\mathrm{x}}$. In general, the BORTAS plume measurements have a range of $\mathrm{NO}_{\mathrm{x}} / \mathrm{NO}_{\mathrm{y}}$ values between 0.0 and 0.4 . The data points in Fig. 12 with $\mathrm{NO}_{\mathrm{x}} / \mathrm{NO}_{\mathrm{y}}$ values greater than 0.4 are measurements made on flight B626 over Northwestern Ontario, indicating that fresher air masses were encountered closer to one of the main source regions. The measure of air mass photochemical age from the ratio of $\mathrm{NO}_{\mathrm{x}} / \mathrm{NO}_{\mathrm{y}}$ is shown relative to the surrogate species $\mathrm{NO}_{\mathrm{z}}$ in Fig. 12c. Measurements with $\mathrm{NO}_{\mathrm{z}}$ mixing ratios less than $1 \mathrm{ppbv}$ were made in both fresh and aged plumes, with the fresher plumes $\left(\mathrm{NO}_{\mathrm{x}} / \mathrm{NO}_{\mathrm{y}}>0.4\right)$ all having higher aerosol loading. Measurements with $\mathrm{NO}_{\mathrm{z}}$ mixing ratios greater than $1 \mathrm{ppbv}$ were all made in aged plumes $\left(\mathrm{NO}_{\mathrm{x}} / \mathrm{NO}_{\mathrm{y}}<0.2\right)$.

Using the measurements used to calculate the photostationary ratio, and including an additional term for the reaction of NO with peroxy radicals in Eq. (1) (Cantrell et al., 2003; Griffin et al., 2007), a photostationary ratio $\Phi_{\mathrm{HO}_{\mathrm{x}} \mathrm{RO}_{\mathrm{x}}}$ 
can be defined:

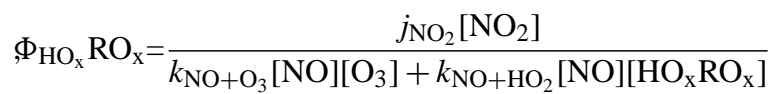

where $k_{\mathrm{NO}+\mathrm{HO} 2}$ is the kinetic rate coefficient for the reaction between $\mathrm{NO}$ and $\mathrm{HO}_{2}$, calculated along the aircraft flight track using the recommended IUPAC definition of $3.6^{-12} \exp (270 / T)$ (Atkinson et al., 2004). Assuming photostationary steady state, we estimate mixing ratios of $\mathrm{HO}_{\mathrm{x}} \mathrm{RO}_{\mathrm{x}}$ required to bring the photostationary ratio to unity by rearranging Eq. (2):

$\left[\mathrm{HO}_{\mathrm{x}} \mathrm{RO}_{\mathrm{x}}\right]=\frac{j_{\mathrm{NO}_{2}}\left[\mathrm{NO}_{2}\right]}{k_{\mathrm{NO}+\mathrm{HO}_{2}}[\mathrm{NO}]}-\frac{k_{\mathrm{NO}+\mathrm{O}_{3}}\left[\mathrm{O}_{3}\right]}{k_{\mathrm{NO}+\mathrm{HO}_{2}}}$

Figure $12 \mathrm{~d}$ shows the $\mathrm{HO}_{\mathrm{x}} \mathrm{RO}_{\mathrm{x}}$ mixing ratios estimated from the BORTAS plume measurements using Eq. (3) versus the $\mathrm{NO}_{\mathrm{x}} / \mathrm{NO}_{\mathrm{y}}$ ratio. The measurements that were closer to unity in Fig. 12a and b (i.e. night-time or with low aerosol loading) generally show the lowest $\mathrm{HO}_{\mathrm{x}} \mathrm{RO}_{\mathrm{x}}$ mixing ratios with values below $0.1 \mathrm{ppbv}$. For the plume measurements with high aerosol loading, the estimated $\mathrm{HO}_{\mathrm{x}} \mathrm{RO}_{\mathrm{x}}$ mixing ratios are generally greater than $0.1 \mathrm{ppbv}$ and extend up to approximately 0.4 ppbv. In the fresher plumes (i.e. $\mathrm{NO}_{\mathrm{x}} / \mathrm{NO}_{\mathrm{y}}>0.4$ ), the $\mathrm{HO}_{\mathrm{x}} \mathrm{RO}_{\mathrm{x}}$ mixing ratios are estimated to be just over $0.1 \mathrm{ppbv}$, with higher mixing ratios generally associated with more aged plumes. The calculated $\mathrm{HO}_{\mathrm{x}} \mathrm{RO}_{\mathrm{x}}$ mixing ratios are consistent with values between 0 and 0.35 ppbv calculated from measurements at a ground-based rural site in the northeastern USA (Griffin et al., 2007).

\subsubsection{Comparison of $\mathrm{O}_{3}$ photochemistry from BORTAS and previous campaigns}

We put the BORTAS plume measurements into context through comparisons with previous aircraft measurement campaigns with a focus over the central and eastern Canada, and sampled outflow from boreal biomass burning. Measurements from two different campaigns are used for this contextual analysis: the NASA ARCTAS-B measurement campaign during the summer of 2008 (Jacob et al., 2010); and the NASA ABLE 3B measurement campaign during the summer of 1990 (Harriss et al., 1994).

Figure 13 shows a comparison of $\mathrm{O}_{3}$ production diagnostics (i.e. $\log _{10}\left(\Delta \mathrm{O}_{3}-\Delta \mathrm{CO}\right)$ vs. $\Delta \mathrm{O}_{3} / \Delta \mathrm{CO}$ and $\mathrm{O}_{\mathrm{x}}$ vs. $\mathrm{NO}_{\mathrm{z}}$ ) derived from aircraft measurements made in biomass burning plumes during ARCTAS-B between 29 June and 13 July 2008 (Fig. 13a and b) and ABLE 3B between 6 July and 15 August 1990 (Fig. 13c and d). For the ARCTAS-B measurements we use $60 \mathrm{~s}$ averaged measurements of $\mathrm{O}_{3}, \mathrm{NO}$, $\mathrm{NO}_{2}$ and $\mathrm{NO}_{\mathrm{y}}$ made by chemiluminescence (Weinheimer et al., 1994), CO made by Tunable Diode Laser Absorption Spectroscopy (TDLAS) (Sachse et al., 1987), $\mathrm{CH}_{3} \mathrm{CN}$ made by PTR-MS (Wisthaler et al., 2002), and black carbon from SP2 (Moteki and Kondo, 2007; Kondo et al., 2011). For comparison against the BORTAS measurements, the ARCTAS-B data are filtered to cover a similar ranges of altitude $(0.5-8.0 \mathrm{~km})$, longitude $\left(110-50^{\circ} \mathrm{W}\right)$, and latitude $\left(40-60^{\circ} \mathrm{N}\right)$. Plume measurements are determined as for the BORTAS measurements, with $\mathrm{CH}_{3} \mathrm{CN}$ mixing ratios in excess of $150 \mathrm{pptv}$, and high aerosol loading is determined for black carbon mass concentrations greater than $0.1 \mu \mathrm{g} \mathrm{cm}^{-3}$. For the ABLE 3B measurements we use $90 \mathrm{~s}$ averaged measurements of $\mathrm{O}_{3}, \mathrm{NO}, \mathrm{NO}_{2}$ and $\mathrm{NO}_{\mathrm{y}}, \mathrm{CO}$, and carbon tetrachloride $\left(\mathrm{C}_{2} \mathrm{Cl}_{4}\right)$ (Blake et al., 1994; Harriss et al., 1994; Sandholm et al., 1994; Wofsy et al., 1994). The ABLE 3B deployment was very similar to that of BORTAS, with measurements extending from Northwest Territories and northern Manitoba across Ontario and Quebec to the east coast of Labrador. No $\mathrm{CH}_{3} \mathrm{CN}$ measurements were made during ABLE 3B and plume measurements are determined from where measurements of $\mathrm{C}_{2} \mathrm{Cl}_{4}$ mixing ratios, a tracer of anthropogenic emissions (Wofsy et al., 1994), were below 20 pptv and CO mixing ratios were greater than 150 ppbv. The aerosol loading in the plume measurements are determined from concentrations of total fine $(0.195-3.12 \mu \mathrm{m})$ and coarse $(0.5-8.0 \mu \mathrm{m})$ particles greater than $20 \mathrm{~cm}^{-3}$.

The ARCTAS-B measurements shown in Fig. 13a, b show similar distributions to the BORTAS measurements shown in Figs. 7 and $8 \mathrm{~b}$, respectively. The variability in the ARCTAS-B $\Delta \mathrm{O}_{3} / \Delta \mathrm{CO}$ ratios is controlled by $\Delta \mathrm{O}_{3}$ in air masses with photochemical ages greater than 4 days, although, as with the BORTAS data, a wide range of $\triangle \mathrm{O}_{3} / \Delta C O$ ratios were observed in air masses with these ages. The relationship between $\mathrm{O}_{\mathrm{x}}$ and $\mathrm{NO}_{z}$ in the ARCTAS-B data also shows a distinctive "L-shaped" distribution, with relatively higher $\mathrm{NO}_{z}$ (greater than $1 \mathrm{ppbv}$ ) and lower $\mathrm{O}_{\mathrm{x}}$ (less than $60 \mathrm{ppbv}$ ) mixing ratios in plume measurements with high aerosol loading, and lower $\mathrm{NO}_{z}$ /higher $\mathrm{O}_{\mathrm{x}}$ associated with low aerosol loading. Slopes of straight lines fitted to the ARCTAS-B data give OPEs relative to $\mathrm{NO}_{\mathrm{z}}$ of $4.6 \pm 31.7 \mathrm{ppbv} \mathrm{ppbv}^{-1}$ for the high aerosol measurements and $107.8 \pm 5.0 \mathrm{ppbv} \mathrm{ppbv}^{-1}$ for the low aerosol measurements. The increased high aerosol OPE and decreased low aerosol OPE compared against the BORTAS measurements further reflect that ARCTAS-B sampled fresher, nearfield, biomass burning plumes. The ABLE 3B measurement campaign made considerably less measurements in biomass burning plumes than BORTAS and ARCTAS-B. Figure 13c shows that the ABLE 3B measurements that are attributed to biomass burning plumes, as described above, had $\Delta \mathrm{O}_{3} / \Delta \mathrm{CO}$ ratios between 0.1 and $1.0 \mathrm{ppbv} \mathrm{ppbv}^{-1}$, indicating that $\Delta \mathrm{O}_{3}$ was always less than $\triangle \mathrm{CO}$ in the ABLE $3 \mathrm{~B}$ measurements. In general, the ABLE 3B measurements were shown to have relative high aerosol loading and the OPE relative to $\mathrm{NO}_{\mathrm{z}}$, Fig. 13d, was calculated to be $5.4 \pm 49.2$ ppbv ppbv $^{-1}$, consistent with the high aerosol OPE values calculated for BORTAS and ARCTAS-B.

Figure 14 shows the relationship between $\mathrm{O}_{3}$ mixing ratio and OPE in boreal biomass burning plumes for the BORTAS, ARCTAS-B, and ABLE 3B measurement campaigns. 
(a)

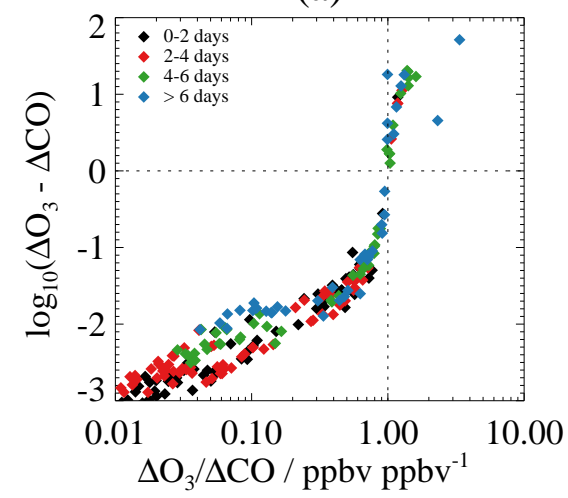

(c)

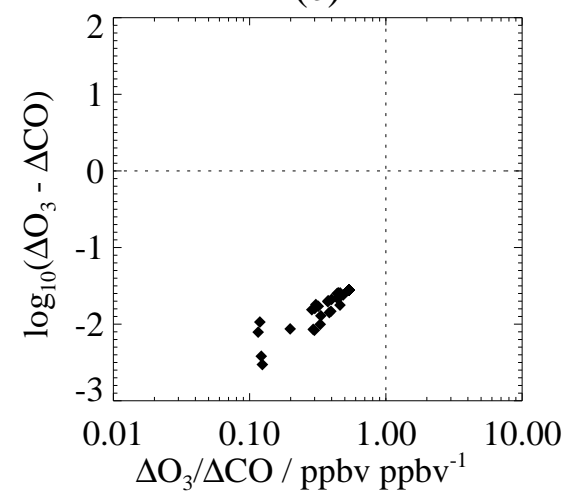

(b)

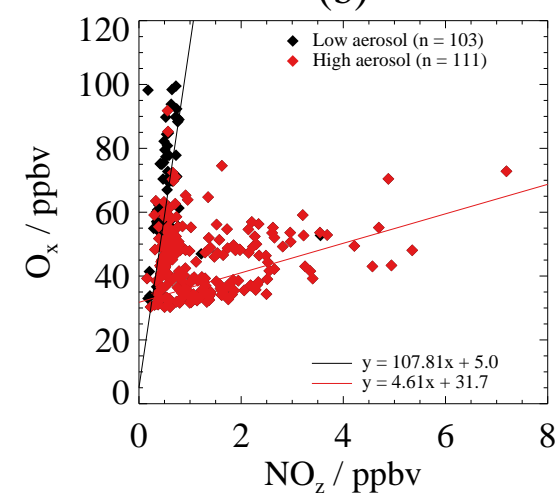

(d)

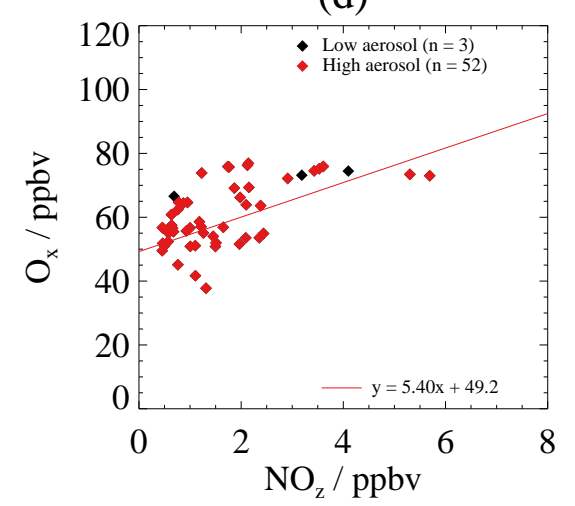

Fig. 13. Relationships between (a) $\Delta \mathrm{O}_{3}$ and $\Delta \mathrm{CO}$, following Fig. 7, and (b) $\mathrm{O}_{\mathrm{x}}$ and $\mathrm{NO}_{\mathrm{z}}$, following Fig. 8b, from aircraft measurements made in biomass burning plumes during ARCTAS-B in the summer of 2008, and (c) $\Delta \mathrm{O}_{3}$ and $\Delta \mathrm{CO}$ and (d) $\mathrm{O}_{\mathrm{x}}$ and $\mathrm{NO}_{\mathrm{z}}$ from aircraft measurements made in biomass burning plumes during ABLE 3B in the summer of 1990.

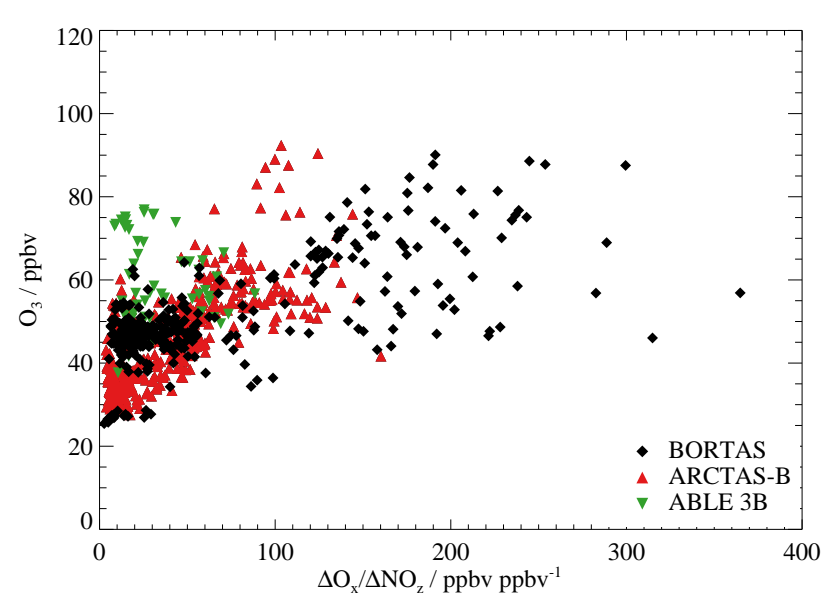

Fig. 14. Relationship between $\mathrm{O}_{3}$ mixing ratio and OPE in boreal biomass burning plumes calculated from aircraft measurements made by the BORTAS (black diamonds), ARCTAS-B (red upward triangles), and ABLE 3B (green downward triangles) campaigns over eastern Canada.
The measurements with low OPE, less than $80 \mathrm{ppbv} p p b v^{-1}$, show a range of $\mathrm{O}_{3}$ mixing ratios between 25 and $80 \mathrm{ppbv}$ and show clear distinctions between the measurements made during the three campaigns. The lowest $\mathrm{O}_{3}$ mixing ratios (25-30 ppbv) were measured on BORTAS flight B626, and the ARCTAS-B measurements typically lie between these values and $\mathrm{O}_{3}$ mixing ratios measured on the other BORTAS flights, which range from approximately 40 to 55 ppbv. The ABLE 3B measurements at these lower OPEs have higher $\mathrm{O}_{3}$ mixing ratios, 55-80 ppbv. Higher $\mathrm{O}_{3}$ mixing ratios, 50-80 ppbv, are observed for OPEs between 80 and $180 \mathrm{ppbv} \mathrm{ppvv}^{-1}$ for the ARCTAS-B measurements, and greater than $100 \mathrm{ppbv} \mathrm{ppbv}^{-1}$ for the BORTAS measurements corresponding to aged plumes with $\mathrm{NO}_{\mathrm{x}} / \mathrm{NO}_{\mathrm{y}}$ ratios $<0.2 \mathrm{ppbv} \mathrm{ppbv}^{-1}$ (see Fig. 12c) and low aerosol loading.

\section{Conclusions}

We have presented an analysis of $\mathrm{O}_{3}$ photochemistry from in situ aircraft measurements made in boreal biomass burning plumes from a synthesis of aircraft measurements made 
over eastern Canada during July and August 2011 as part of the BORTAS measurement campaign. We evaluated the tropospheric $\mathrm{O}_{3}$ distribution observed over the course of the measurement campaign and the potential for quantifying the photochemical processes that influence $\mathrm{O}_{3}$ production and loss within boreal biomass burning plumes. The range of the measured $\mathrm{O}_{3}$ mixing ratios was typically between 45 and 70 ppbv, based on the lower and upper quartiles of the measurements on each research flight. Over the campaign, as a whole, there was no distinguishable difference between $\mathrm{O}_{3}$ measurements made within plume and those made in clean air. At the highest values of $\mathrm{CO}$ (> $300 \mathrm{ppbv}$ ) we observed a relatively narrow range of $\mathrm{O}_{3}$ mixing ratios between approximately 40 and $60 \mathrm{ppbv}$. We evaluated photochemical processes influencing the observed $\mathrm{O}_{3}$ distribution using a number of different measurements made from the aircraft throughout the campaign. First, photochemical ageing of the plume measurements was determined using canister samples of different alkanes and their relationship to $\mathrm{O}_{3}$ enhancements relative to $\mathrm{CO}$. Second, the relative contributions of photochemical cycling of $\mathrm{NO}_{\mathrm{x}}$ and peroxy radicals was analysed assuming photochemical steady state.

We calculated photochemical ages of the measured plumes using ratios of different alkanes assuming a common sink through oxidation with $\mathrm{OH}$ (Parrish et al., 2007) and found values that were consistent with previous measurements of biomass burning plumes. We used these ratios to estimate that plumes sampled during the campaign ranged in age from 0 to 10 days, indicating that the BORTAS measurements sampled a wider range of plume ages over previous measurement campaigns due to fires in Northwestern Ontario. When biomass burning plume measurements were evaluated relative to these estimated ages, we found that the highest measured values of $\mathrm{CO}$ and $\mathrm{CH}_{3} \mathrm{CN}$ occurred at ages of 2-3 days, and distances of approximately 1000$3000 \mathrm{~km}$ from the expected emissions sources, reflecting the transport time of the plume to where it was intercepted by the aircraft. We calculated $\mathrm{O}_{3}$ production in boreal biomass burning plumes, using $\Delta \mathrm{O}_{3} / \Delta \mathrm{CO}$ enhancement ratios, to be $0.020 \pm 0.009 \mathrm{ppbv} \mathrm{ppbv}^{-1}$ for plume ages less than 2 days, which increased to $0.13 \pm 0.10 \mathrm{ppbv} \mathrm{ppbv}^{-1}$ for plume ages between 2 and 5 days, and to $0.75 \pm 0.41 \mathrm{ppbv} \mathrm{ppbv}^{-1}$ for plume ages greater than 5 days. The $\Delta \mathrm{O}_{3} / \Delta \mathrm{CO}$ enhancement ratio indicated that net $\mathrm{O}_{3}$ production in boreal biomass burning plumes is a function of photochemical age, consistent with a recent review of $\mathrm{O}_{3}$ production in boreal biomass burning outflow (Jaffe and Wigder, 2012). The $\Delta \mathrm{O}_{3} / \Delta \mathrm{CO}$ ratios calculated for the BORTAS measurements were controlled by $\Delta \mathrm{O}_{3}$ after 4 days and a combination of $\Delta \mathrm{O}_{3}$ and $\Delta \mathrm{CO}$ prior to that.

We performed a detailed analysis of the photochemical processes influencing the $\mathrm{O}_{3}$ distribution in boreal biomass burning plumes using measurements of total alkyl nitrates $(\Sigma \mathrm{AN}), \mathrm{NO}_{\mathrm{x}}$ and $\mathrm{NO}_{\mathrm{y}}$ made from the aircraft. Through comparing plume $\mathrm{O}_{3}$ mixing ratios with $\Sigma \mathrm{AN}$ and the surrogate species $\mathrm{NO}_{\mathrm{z}}$, we found that $\mathrm{O}_{3}$ production was suppressed in relatively fresh plumes (photochemical ages less than 4 days) with between $7.7 \pm 3.5 \mathrm{ppbv}$ of $\mathrm{O}_{\mathrm{x}}$ produced per ppbv of $\Sigma \mathrm{AN}$ and $1.6 \pm 0.9 \mathrm{ppbv}$ of $\mathrm{O}_{\mathrm{x}}$ produced per ppbv of $\mathrm{NO}_{\mathrm{x}}$ that was oxidised. In aged plumes the OPE increased significantly to $472 \pm 28$ ppbv $\mathrm{O}_{\mathrm{x}}$ per ppbv $\Sigma$ AN and $155 \pm 5$ ppbv $\mathrm{O}_{\mathrm{x}}$ perppbv $\mathrm{NO}_{\mathrm{z}}$. We found that the plume OPE was strongly correlated with the aerosol loading of the air mass, with higher aerosol loading (black carbon mass concentration $>0.1 \mu \mathrm{g} \mathrm{cm}^{-3}$ ) generally associated with younger plumes and lower enhancement ratios of $\Delta \mathrm{O}_{\mathrm{x}} / \Delta \mathrm{NO}_{\mathrm{z}}$, and lower aerosol loading (black carbon mass concentration $<0.1 \mu \mathrm{g} \mathrm{cm}^{-3}$ ) in plumes that are more aged. When compared against $\mathrm{NO}_{\mathrm{x}}$, the $\Delta \mathrm{O}_{\mathrm{x}} / \Delta \mathrm{NO}_{\mathrm{z}}$ ratios indicated that the BORTAS plume measurements were made in different chemical regimes: a more VOC-limited regime for flight B626 and the high aerosol loading measurements, and a more $\mathrm{NO}_{\mathrm{x}}$-limited regime for the low aerosol loading measurements. Furthermore, we found that measurements of plume air with high aerosol loading and relatively low OPE were made at high relative humidity $(>40 \%)$ throughout the vertical extent of the aircraft measurements, and the low aerosol plumes with relatively high OPE were made at low relative humidity and generally higher altitude (typically above $4 \mathrm{~km}$ ).

When the BORTAS measurements were compared to similar measurements made in boreal biomass burning plumes over eastern Canada by the ARCTAS-B and ABLE 3B campaigns, we found that OPE increased with plume ages calculated by NMHC ratios. In all campaign measurements we found that plumes with high aerosol loading typically had low OPE, less than $80 \mathrm{ppbv} \mathrm{ppbv}^{-1}$, and aged plumes were typically associated with low aerosol loading and relatively high OPE. We showed that on one of the BORTAS flights, which made multiple interceptions of a plume with high aerosol loading, $j_{\mathrm{NO}_{2}}$ was reduced by a factor of approximately 2 within the plume, suggesting that increased optical depth of the plume attenuated the actinic flux and subsequent photolysis of $\mathrm{NO}_{2}$ to form $\mathrm{O}_{3}$. However, as $j_{\mathrm{NO}_{2}}$ was not reduced completely to zero, the relatively low OPE in these plumes could also be due to other in-plume processes such as potential loss of $\mathrm{O}_{3}$ and $\mathrm{NO}_{\mathrm{y}}$ species through heterogeneous uptake by aerosol in biomass burning plumes (Longfellow et al., 2000; Grassian, 2001) or light-induced heterogeneous photochemical $\mathrm{O}_{3}$ loss on the surface of biomass burning aerosols that increases with relative humidity (Konovalov et al., 2012).

Other potential factors not considered in the analysis presented here could have influenced the tropospheric $\mathrm{O}_{3}$ distribution observed over the course of the BORTAS campaign. Some of the BORTAS measurements were potentially made downwind of anthropogenic emissions sources, such as the northeastern US and the Alberta tar sands, and while great care was taken to avoid pollution outflow from these sources in the deployment of the BORTAS aircraft campaign they 
could have provided additional sources of VOCs and $\mathrm{NO}_{\mathrm{x}}$ (from PAN decomposition) and influenced $\mathrm{O}_{3}$ production over the BORTAS region. Measurements were also made downwind of lightning activity across North America and could have provided an additional source of $\mathrm{NO}_{\mathrm{x}}$ in the free troposphere. While $\mathrm{O}_{3}$ enhancements in boreal biomass burning plumes with low aerosol loading and low relative humidity could have been influenced by mixing of the plumes with air of stratospheric origin, the highest $\mathrm{O}_{3}$ mixing ratios measured during BORTAS were generally less than $100 \mathrm{ppbv}$ and lower than typical stratospheric $\mathrm{O}_{3}$ mixing ratios. Empirical, observation-based methods provide a powerful tool for diagnosing $\mathrm{O}_{3}$ photochemistry and $\mathrm{NO}_{\mathrm{y}}$ speciation associated with biomass burning. The observational analysis presented here is being investigated further using detailed chemical modelling and will be the subject of future publications using the BORTAS data.

Acknowledgements. The BORTAS project is funded by the Natural Environment Research Council (NERC) under grant NE/F017391/1. Airborne data were obtained using the BAe146-301 Atmospheric Research Aircraft (ARA) operated by Directflight Ltd (DFL) and managed by the Facility for Airborne Atmospheric Measurements (FAAM), which is a joint entity of NERC and the UK Meteorological Office. We acknowledge the great efforts provided by the staff of FAAM, DFL, Avalon Aero Ltd and Captains Alan Foster and Charlie Whittaker and First Officer Ian Ramsay-Rae. The ARCTAS-B 60-s merges were obtained from the POLARCAT/ARCTAS archive at the NASA Langley Research Center Atmospheric Science Data Center (LaRC DACC). The ABLE 3B 90-s merges were obtained from the NASA Global Tropospheric Experiment data archive at the LaRC DACC. We acknowledge Andrew Weinheimer, Armin Wisthaler, Glenn Diskin, and Yutaka Kondo for their respective measurements of $\mathrm{NO}_{\mathrm{x}} / \mathrm{NO}_{\mathrm{y}} / \mathrm{O}_{3}, \mathrm{CH}_{3} \mathrm{CN}, \mathrm{CO}$, and black carbon made during the ARCTAS-B measurement campaign as well as the science teams of ARCTAS and ABLE 3B for use of the measurements taken during each campaign.

Edited by: B. N. Duncan

\section{References}

Alvarado, M. J., Logan, J. A., Mao, J., Apel, E., Riemer, D., Blake, D., Cohen, R. C., Min, K.-E., Perring, A. E., Browne, E. C., Wooldridge, P. J., Diskin, G. S., Sachse, G. W., Fuelberg, H., Sessions, W. R., Harrigan, D. L., Huey, G., Liao, J., Case-Hanks, A., Jimenez, J. L., Cubison, M. J., Vay, S. A., Weinheimer, A. J., Knapp, D. J., Montzka, D. D., Flocke, F. M., Pollack, I. B., Wennberg, P. O., Kurten, A., Crounse, J., Clair, J. M. St., Wisthaler, A., Mikoviny, T., Yantosca, R. M., Carouge, C. C., and Le Sager, P.: Nitrogen oxides and PAN in plumes from boreal fires during ARCTAS-B and their impact on ozone: an integrated analysis of aircraft and satellite observations, Atmos. Chem. Phys., 10, 9739-9760, doi:10.5194/acp-10-9739-2010, 2010.

Anderson, B. E., Gregory, G. L., Barrick, J. D. W., Collins Jr., J. E., Sachse, G. W., Shipham, M. C., and Hudgins, C. H.: Summer- time tropospheric ozone distributions over central and eastern Canada, J. Geophys. Res., 99, 1781-1792, 1994.

Anderson, T. L. and Ogren, J. A.: Determining aerosol radiative properties using the TSI 3563 integrating nephelometer, Aerosol Sci. Technol., 29, 57-69, 1998.

Atkinson, R. and Arey, J.: Atmospheric degradation of volatile organic compounds, Chem. Rev., 103, 4605-4638, 2003.

Atkinson, R., Baulch, D. L., Cox, R. A., Crowley, J. N., Hampson, R. F., Hynes, R. G., Jenkin, M. E., Rossi, M. J., and Troe, J.: Evaluated kinetic and photochemical data for atmospheric chemistry: Volume $\mathrm{I}-$ gas phase reactions of $\mathrm{O}_{\mathrm{x}}, \mathrm{HO}_{\mathrm{x}}, \mathrm{NO}_{\mathrm{x}}$ and $\mathrm{SO}_{\mathrm{x}}$ species, Atmos. Chem. Phys., 4, 1461-1738, doi:10.5194/acp-41461-2004, 2004.

Bange, H. W. and Williams, J.: New directions: Acetonitrile in atmospheric and biogeochemical cycles, Atmos. Environ., 34, 4959-4960, 2000.

Bertschi, I. T. and Jaffe, D. A.: Long-range transport of ozone, carbon monoxide, and aerosols to the NE Pacific troposphere during the summer of 2003: Observations of smoke plumes from Asian boreal fires, J. Geophys. Res., 110, D05303, doi:10.1029/2004JD005135, 2005.

Blake, D. R., Smith, Jr., T. W., Chen, T.-Y., Whipple, W. J., and Rowland, F. S.: Effects of biomass burning on summertime nonmethane hydrocarbon concentrations in the Canadian wetlands, J. Geophys. Res., 99, 1699-1719, 1994.

Cantrell, C. A., Mauldin, L., Zondlo, M., Eisele, F., Kosiuch, E., Shetter, R., Lefer, B., Hall, S., Campos, T., Ridley, B., Walega, J., Fried, A., Wert, B., Flocke, F., Weinheimer, A., Hannigan, J., Coffey, M., Atlas, E., Stephens, S., Heikes, B., Snow, J., Blake, D., Blake, N., Katzenstein, A., Lopez, J., Browell, E. V., Dibb, J., Scheuer, E., Seid, G., and Talbot, R.: Steady state free radical budgets and ozone photochemistry during TOPSE, J. Geophys. Res., 108, 8361, doi:10.1029/2002JD002198, 2003.

Chin, M., Jacob, D. J., and Munger, J. W.: Relationship of ozone and carbon monoxide over North America, J. Geophys. Res., 99, 14565-14573, 1994.

Cook, P. A., Savage, N. H., Turquety, S., Carver, G. D., O’Connor, F. M., Heckel, A., Stewart, D., Whalley, L. K., Parker, A. E., Schlager, H., Singh, H. B., Avery, M. A., Sachse, G. W., Brune, W., Richter, A., Burrows, J. P., Purvis, R., Lewis, A. C., Reeves, C. E., Monks, P. S., Levine, J. G., and Pyle, J. A.: Forest fire plumes over the North Atlantic: p-TOMCAT model simulations with aircraft and satellite measurements from the ITOP/ICARTT campaign, J. Geophys. Res., 112, D10S43, doi:10.1029/2006JD007563, 2007.

Dari-Salisburgo, C., Di Carlo, P., Giammaria, F., Kajii, Y., and D'Altorio, A.: Laser induced fluorescence instrument for $\mathrm{NO}_{2}$ measurements: Observations at a central Italy background site, Atmos. Environ., 43, 970-977, 2009.

Daum, P. H., Kleinman, L. I., Imre, D., Nunnermacker, L. J., Lee, Y.-N., Springston, S. R., and Newman, L.: Analysis of $\mathrm{O}_{3}$ formation during a stagnation episode in central Tennessee in summer 1995, J. Geophys. Res., 105, 9107-9119, 2000.

Davis, D. D., Crawford, J., Chen, G., Chameides, W., Liu, S., Bradshaw, J., Sandholm, S., Sachse, G., Gregory, G., Anderson, B., Barrick, J., Bachmeier, A., Collins, J., Browell, E., Blake, D., Rowland, S., Kondo, Y., Singh, H., Talbot, R., Heikes, B., Merrill, J., Rodriguez, J., and Newell, R. E.: Assessment of ozone photochemistry in the western North Pacific as inferred from 
PEM-West A observations during the fall 1991, J. Geophys. Res., 101, 2111-2134, 1996.

Day, D. A., Dillon, M. B., Wooldridge, P. J., Thornton, J. A., Rosen, R. S., Wood, E. C., and Cohen, R. C.: On alkyl nitrates, $\mathrm{O}_{3}$, and the "missing $\mathrm{NO}_{\mathrm{y}}$ ", J. Geophys. Res., 108, 4501, doi:10.1029/2003JD003685, 2003.

DeBell, L. J., Talbot, R. W., Dibb, J. E., Munger, J. W., Fischer, E. V., and Frolking, S. E.: A major regional air pollution event in the northeastern United States caused by extensive forest fires in Quebec, Canada, J. Geophys. Res., 109, D19305, doi:10.1029/2004JD004840, 2004.

Di Carlo, P., Aruffo, E., Busilacchio, M., Giammaria, F., DariSalisburgo, C., Biancofiore, F., Visconti, G., Lee, J., Moller, S., Reeves, C. E., Bauguitte, S., Forster, G., Jones, R. L., and Ouyang, B.: Aircraft based four-channel thermal dissociation laser induced fluorescence instrument for simultaneous measurements of $\mathrm{NO} 2$, total peroxy nitrate, total alkyl nitrate, and $\mathrm{HNO}_{3}$, Atmos. Meas. Tech., 6, 971-980, doi:10.5194/amt-6-971-2013, 2013.

Fehsenfeld, F. C., Ancellet, G., Bates, T. S., Goldstein, A. H., Hardesty, R. M., Honrath, R., Law, K. S., Lewis, A. C., Leaitch, R., McKeen, S., Meagher, J., Parrish, D. D., Pszenny, A. A. P., Russell, P. B., Schlager, H., Seinfeld, J., Talbot, R., and Zbinden, R.: International Consortium for Atmospheric Research on Transport and Transformation (ICARTT): North America to Europe Overview of the 2004 summer field study, J. Geophys. Res., 111, D23S01, doi:10.1029/2006JD007829, 2006.

Franklin, J. E., Drummond, J. R., Griffin, D., Pierce, J. R., Waugh, D. L., Palmer, P. I., Parrington, M., Lee, J. D., Lewis, A. C., Rickard, A. R., Taylor, J., Chisholm, L., Duck, T. J., Hopper, J. T., Gibson, M., Curry, K. R., Sakamoto, K. M., Lesins, G., Walker, K. A., Dan, L., and Kliever, J.: A case study of aerosol depletion in a biomass burning plume over Eastern Canada during the 2011 BORTAS field experiment, in preparation, 2013.

Gerbig, C., Schmitgen, S., Kley, D., and Volz-Thomas, A.: An improved fast-response vacuum-UV resonance fluorescence $\mathrm{CO}$ instrument, J. Geophys. Res., 104, 1699-1704, 1999.

Goode, J. G., Yokelson, R. J., Ward, D. E., Susott, R. A., Babbitt, R. E., Davies, M. A., and Hao, W. M.: Measurements of excess $\mathrm{O}_{3}, \mathrm{CO}_{2}, \mathrm{CO}, \mathrm{CH}_{4}, \mathrm{C}_{2} \mathrm{H}_{4}, \mathrm{C}_{2} \mathrm{H}_{2}, \mathrm{HCN}, \mathrm{NO}, \mathrm{NH}_{3}$, $\mathrm{HCOOH}, \mathrm{CH}_{3} \mathrm{COOH}, \mathrm{HCHO}$, and $\mathrm{CH}_{3} \mathrm{OH}$ in 1997 Alaskan biomass burning plumes by airborne Fourier transform infrared spectroscopy (AFTIR), J. Geophys. Res., 105, 22147-22166, 2000.

Grassian, V. H.: Heterogeneous uptake and reaction of nitrogen oxides and volatile organic compounds on the surface of atmospheric particles including oxides, carbonates, soot and mineral dust: Implications for the chemical balance of the troposphere, Int. Rev. Phys. Chem., 20, 467-548, 2001.

Griffin, D., Walker, K. A., Franklin, J. E., Parrington, M., Whaley, C., Hopper, J., Drummond, J. R., Palmer, P. I., Strong, K., Duck, T. J., Abboud, I., Bernath, P. F., Clerbaux, C., Coheur, P.F., Curry, K. R., Dan, L., Hyer, E., Kliever, J., Lesins, G., Maurice, M., Saha, A., Tereszchuk, K., and Weaver, D.: Investigation of $\mathrm{CO}, \mathrm{C}_{2} \mathrm{H}_{6}$ and aerosols in a boreal fire plume over eastern Canada during BORTAS 2011 using ground- and satellitebased observations, and model simulations, Atmos. Chem. Phys. Discuss., 13, 11071-11109, doi:10.5194/acpd-13-11071-2013, 2013.
Griffin, R. J., Beckman, P. J., Talbot, R. W., Sive, B. C., and Varner, R. K.: Deviations from ozone photostationary state during the International Consortium for Atmospheric Research on Transport and Transformation 2004 campaign: Use of measurements and photochemical modeling to assess potential causes, J. Geophys. Res., 112, D10S07, doi:10.1029:/2006JD007604, 2007.

Harriss, R. C., Wofsy, S. C., S., B. D., Shipham, M. C., Jacob, D. J., Hoell Jr., J. M., Bendura, R. J., Drewry, J. W., McNeal, R. J., Navarro, R. L., Gidge, R. N., and Rabine, V. E.: The Arctic Boundary Layer Expedition (ABLE 3A): July-August 1988, J. Geophys. Res., 97, 16383-16394, 1992.

Harriss, R. C., Wofsy, S. C., Hoell Jr., J. M., Bendura, R. J., Drewry, J. W., McNeal, R. J., Pierce, D., Rabine, V., and Snell, R. L.: The Arctic Boundary Layer Expedition (ABLE 3B): July-August 1990, J. Geophys. Res., 99, 1635, 1994.

Helmig, D., Tanner, D. M., Honrath, R. E., Owen, R. C., and Parrish, D. D.: Nonmethane hydrocarbons at Pico Mountain, Azores: 1. Oxidation chemistry in the North Atlantic region, J. Geophys. Res., 113, D20S91, doi:10.1029/2007JD008930, 2008.

Honrath, R. E., Owen, R. C., Val Martin, M., Reid, J. S., Lapina, K., Fialho, P., Dziobak, M. P., Kleissl, J., and Westphal, D. L.: Regional and hemispheric impacts of anthropogenic and biomass burning emissions on summertime $\mathrm{CO}$ and $\mathrm{O}_{3}$ in the North Atlantic lower free troposphere, J. Geophys. Res., 109, D24310, doi:10.1029/2004JD005147, 2004.

Hopkins, J. R., Lewis, A. C., and Read, K. A.: A two-column method for long-term monitoring of non-methane hydrocarbons (NMHCs) and oxygenated volatile organic compounds (oVOCs), J. Environ. Monitor., 5, 8-13, 2003.

Hopkins, J. R., Jones, C. E., and Lewis, A. C.: A dual channel gas chromatograph for atmospheric analysis of volatile organic compounds including oxygenated and monoterpene compounds, J. Environ. Monitor., 13, 2268-2276, 2011.

Jacob, D. J., Crawford, J. H., Maring, H., Clarke, A. D., Dibb, J. E., Emmons, L. K., Ferrare, R. A., Hostetler, C. A., Russell, P. B., Singh, H. B., Thompson, A. M., Shaw, G. E., McCauley, E., Pederson, J. R., and Fisher, J. A.: The Arctic Research of the Composition of the Troposphere from Aircraft and Satellites (ARCTAS) mission: design, execution, and first results, Atmos. Chem. Phys., 10, 5191-5212, doi:10.5194/acp-10-5191-2010, 2010.

Jaffe, D. A. and Wigder, N. L.: Ozone production from wildfires: A critical review, Atmos. Environ., 51, 1-10, 2012.

Jobson, B. T., Wu, Z., Niki, H., and Barrie, L. A.: Seasonal trends of isoprene, $\mathrm{C}_{2}-\mathrm{C}_{5}$ alkanes, and acetylene at a remote boreal site in Canada, J. Geophys. Res., 99, 1589-1599, 1994.

Kleinman, L. I.: Ozone process insights from field experiments part II: Observation-based analysis for ozone production, Atmos. Environ., 34, 2023-2033, 2000.

Kondo, Y., Matsui, H., Moteki, N., Sahu, L., Takegawa, N., Kajino, M., Zhao, Y., Cubison, M. J., Jimenez, J. L., Vay, S., Diskin, G. S., Anderson, B., Wisthaler, A., Mikoviny, T., Fuelberg, H. E., Blake, D. R., Huey, G., Weinheimer, A. J., Knapp, D. J., and Brune, W. H.: Emissions of black carbon, organic, and inorganic aerosols from biomass burning in North America and Asia in 2008, J. Geophys. Res., 116, D08204, doi:10.1029/2010JD015152, 2011.

Konovalov, I. B., Beekman, M., D'Anna, B., and George, C.: Significant light induced ozone loss on biomass burning aerosol: Evidence from chemistry-transport modeling based 
on new laboratory studies, Geophys. Res. Lett., 39, L17807, doi:10.1029/2012GL052432, 2012.

Laborde, M., Mertes, P., Zieger, P., Dommen, J., Baltensperger, U., and Gysel, M.: Sensitivity of the Single Particle Soot Photometer to different black carbon types, Atmospheric Measurement Techniques, 5, 1031-1043, 2012.

Lapina, K., Honrath, R. E., Owen, R. C., Val Martin, M., and Pfister, G.: Evidence of significant large-scale impacts of boreal fires on ozone levels in the midlatitude Northern Hemisphere free troposphere, Geophys. Res. Lett., 33, L10815, doi:10.1029/2006GL025878, 2006.

Latifovic, R., Zhu, Z.-L., Cihlar, J., Giri, C., and Olthof, I.: Land cover mapping of North and Central America - Global Land Cover 2000, Remote Sens. Environ., 89, 116-127, 2004.

Lee, J. D., Moller, S. J., Read, K. A., Lewis, A. C., Mendes, L., and Carpenter, L. J.: Year-round measurements of nitrogen oxides and ozone in the tropical North Atlantic marine boundery layer, J. Geophys. Res., 114, D21302, doi:10.1029/2009JD011878, 2009.

Leighton, P. A.: Photochemistry of air pollution, Phys. Chem., 9, 300 pp., 1961.

Lewis, A. C., Evans, M. J., Methven, J., Watson, N., Lee, J. D., Hopkins, J. R., Purvis, R. M., Arnold, S. R., McQuaid, J. B., Whalley, L. K., Pilling, M. J., Heard, D. E., Monks, P. S., Parker, A. E., Reeves, C. E., Oram, D. E., Mills, G., Bandy, B. J., Stewart, D., Coe, H., Williams, P., and Crosier, J.: Chemical composition observed over the mid-Atlantic and the detection of pollution signatures far from source regions, J. Geophys. Res., 112, D10S39, doi:10.1029/2006JD007584, 2007.

Longfellow, C. A., Ravishankara, A. R., and Hanson, D. R.: Reactive and nonreactive uptake on hydrocarbon soot: $\mathrm{HNO}_{3}, \mathrm{O}_{3}$, and $\mathrm{N}_{2} \mathrm{O}_{5}$, J. Geophys. Res., 105, 24345-24350, 2000.

Mauzerall, D. L., Jacob, D. J., Fan, S.-M., Bradshaw, J. D., Gregory, G. L., Sachse, G. W., and Blake, D. R.: Origin of tropospheric ozone at remote high northern latitudes in summer, J. Geophys. Res., 101, 4175-4188, 1996.

McKeen, S. A., Wotawa, G., Parrish, D. D., Holloway, J. S., Buhr, M. P., Hübler, G., Fehsenfeld, F. C., and Meagher, J. F.: Ozone production from Canadian wildfires during June and July of 1995, J. Geophys. Res., 107, 4192, doi:10.1029/2001JD000697, 2001.

McMeeking, G. R., Hamburger, T., Liu, D., Flynn, M., Morgan, W. T., Northway, M., Highwood, E. J., Krejci, R., Allan, J. D., Minikin, A., and Coe, H.: Black carbon measurements in the boundary layer over western and northern Europe, Atmos. Chem. Phys., 10, 9393-9414, doi:10.5194/acp-10-9393-2010, 2010.

Moteki, N. and Kondo, Y.: Effects of mixing state on black carbon measurements by laser-induced incandescence, Aerosol Sci. Technol., 41, 398-417, 2007.

Murphy, J. G., Oram, D. E., and Reeves, C. E.: Measurements of volatile organic compounds over West Africa, Atmos. Chem. Phys., 10, 5281-5294, doi:10.5194/acp-10-5281-2010, 2010.

Olszyna, K. J., Bailey, E. M., Simonaitis, R., and Meagher, J. F.: $\mathrm{O}_{3}$ and $\mathrm{NO}_{\mathrm{y}}$ relationships at a rural site, J. Geophys. Res., 99, 14557-14563, 1994.

Palmer, P. I., Parrington, M., Lee, J. D., Lewis, A. C., Rickard, A. R., Bernath, P. F., Duck, T. J., Waugh, D. L., Tarasick, D. W., Andrews, S., Aruffo, E., Bailey, L. J., Barrett, E., Bauguitte, S. J.-B., Curry, K. R., Di Carlo, P., Chisholm, L., Dan, L., Forster, G., Franklin, J. E., Gibson, M. D., Griffin, D., Helmig, D., Hop- kins, J. R., Hopper, J. T., Jenkin, M. E., Kindred, D., Kliever, J., Le Breton, M., Matthiesen, S., Maurice, M., Moller, S., Moore, D. P., Oram, D. E., O’Shea, S. J., Owen, R. C., Pagniello, C. M. L. S., Pawson, S., Percival, C. J., Pierce, J. R., Punjabi, S., Purvis, R. M., Remedios, J. J., Rotermund, K. M., Sakamoto, K. M., da Silva, A. M., Strawbridge, K. B., Strong, K., Taylor, J., Trigwell, R., Tereszchuk, K. A., Walker, K. A., Weaver, D., Whaley, C., and Young, J. C.: Quantifying the impact of BOReal forest fires on Tropospheric oxidants over the Atlantic using Aircraft and Satellites (BORTAS) experiment: design, execution and science overview, Atmos. Chem. Phys., 13, 6239-6261, doi:10.5194/acp-13-6239-2013, 2013.

Parrington, M., Palmer, P. I., Henze, D. K., Tarasick, D. W., Hyer, E. J., Owen, R. C., Helmig, D., Clerbaux, C., Bowman, K. W., Deeter, M. N., Barratt, E. M., Coheur, P.-F., Hurtmans, D., Jiang, Z., George, M., and Worden, J. R.: The influence of boreal biomass burning emissions on the distribution of tropospheric ozone over North America and the North Atlantic during 2010, Atmos. Chem. Phys., 12, 2077-2098, doi:10.5194/acp-12-20772012, 2012.

Parrish, D. D., Hahn, C. J., Williams, E. J., Norton, R. B., Fehsenfeld, F. C., Singh, H. B., Shetter, J. D., Gandrud, B. W., and Ridley, B. A.: Indications of photochemical histories of Pacific air masses from measurements of atmospheric trace species at Point Arena, California, J. Geophys. Res., 97, 15883-15901, 1992.

Parrish, D. D., Holloway, J. S., Trainer, M., Murphy, P. C., Forbes, G. L., and Fehsenfeld, F. C.: Export of North American Ozone Pollution to the North Atlantic Ocean, Science, 259, 1436-1439, 1993.

Parrish, D. D., Stohl, A., Forster, C., Atlas, E. L., Blake, D. R., Goldan, P. D., Kuster, W. C., and de Gouw, J. A.: Effects of mixing on evolution of hydrocarbon ratios in the troposphere, J. Geophys. Res., 112, D10S34, doi:10.1029/2006JD007583, 2007.

Perring, A. E., Bertram, T. H., Farmer, D. K., Wooldridge, P. J., Dibb, J., Blake, N. J., Blake, D. R., Singh, H. B., Fuelberg, H., Diskin, G., Sachse, G., and Cohen, R. C.: The production and persistence of $\sum \mathrm{RONO}_{2}$ in the Mexico City plume, Atmos. Chem. Phys., 10, 7215-7229, doi:10.5194/acp-10-72152010, 2010.

Pfister, G. G., Emmons, L. K., Hess, P. G., Honrath, R., Lamarque, J.-F., Val Martin, M., Owen, R. C., Avery, M. A., Browell, E. V., Holloway, J. S., Nedelec, P., Purvis, R., Ryerson, T. B., Sachse, G. W., and Schlager, H.: Ozone production from the 2004 North American boreal fires, J. Geophys. Res., 111, D24S07, doi:10.1029/2006JD007695, 2006.

Real, E., Law, K. S., Weinzierl, B., Fiebig, M., Petzold, A., Wild, O., Methven, J., Arnold, S., Stohl, A., Huntrieser, H., Roiger, A., Schlager, H., Stewart, D., Avery, M., Sachse, G., Browell, E., Ferrare, R., and Blake, D.: Processes influencing ozone levels in Alaskan forest fire plumes during long-range transport over the North Atlantic, J. Geophys. Res., 112, D10S41, doi:10.1029/2006JD007576, 2007.

Rickard, A. R., Salisbury, G., Monks, P. S., Lewis, A. C., Baugitte, S., Bandy, B. J., Clemitshaw, K. C., and Penkett, S. A.: Comparison of measured ozone production efficiencies in the marine boundary layer at two European coastal sites under different pollution regimes, J. Atmos. Chem., 43, 107-134, 2002.

Rudolph, J. and Johnen, F. J.: Measurements of light atmospheric hydrocarbons over the Atlantic in regions of low biological ac- 
tivity, J. Geophys. Res., 95, 20583-20591, 1990.

Ryerson, T. B., Buhr, M. P., Frost, G. J., Goldan, P. D., Holloway, J. S., Hübler, G., Jobson, B. T., Kuster, W. C., McKeen, S. A., Parrish, D. D., Roberts, J. M., Sueper, D. T., Trainer, M., Williams, J., and Fehsenfeld, F. C.: Emissions lifetimes and ozone formation in power plant plumes, J. Geophys. Res., 103, 22569-22583, 1998.

Sachse, G. W., Hill, G. F., Wade, L. O., and Perry, M. G.: Fastresponse, high-precision carbon monoxide sensor using a tunable diode laser absorption technique, J. Geophys. Res., 92, 20712081, 1987.

Sandholm, S., Olson, J., Bradshaw, J., Talbot, R., Singh, H., Gregory, G., Blake, D., Anderson, B., Sachse, G., Barrick, J., Collins, J., Klemm, K., Lefer, B., Klemm, O., Gorzelska, K., Herlth, D., and O'Hara, D.: Summertime partitioning and budget of $\mathrm{NO}_{\mathrm{y}}$ compounds in the troposphere over Alaske and Canada: ABLE 3B, J. Geophys. Res., 99, 1837-1861, 1994.

Schwarz, J. P., Gao, R. S., Fahey, D. W., Thomson, D. S., Watts, L. A., Wilson, J. C., Reeves, J. M., Darbehesti, M., Baumgardner, D. G., Kok, G. L., Chung, S. H., Schulz, M., Hendricks, J., Lauer, A., Kärcher, B., Slowik, J. G., Rosenlof, K. H., Thompson, T. L., Langford, A. O., Loewenstein, M., and Aikin, K. C.: Single-particle measurements of midlatitude black carbon and light-scattering aerosols from the boundary layer to the lower stratosphere, J. Geophys. Res., 111, D16207, doi:10.1029/2006JD007076, 2006.

Sillman, S.: Ozone production efficiency and loss of $\mathrm{NO}_{\mathrm{x}}$ in power plant plumes: Photochemical model and interpretation of measurements in Tennessee, J. Geophys. Res., 105, 9189-9202, 2000.

Singh, H. B., Anderson, B. E., Brune, W. H., Cai, C., Cohen, R. C., Crawford, J. H., Cubison, M. J., Czech, E. P., Emmons, L., Fuelberg, H. E., Huey, G., Jacob, D. J., Jimenez, J. L., Kaduwela, A., Kondo, Y., Mao, J., Olson, J. R., Sachse, G. W., Vay, S. A., Weinheimer, A., Wennberg, P. O., Wisthaler, A., and the ARCTAS Science Team: Pollution influences on atmospheric composition and chemistry at high northern latitudes: Boreal and California forest fire emissions, Atmos. Environ., 44, 4553-4564, 2010.

Spivakovsky, C. M., Logan, J. A., Montzka, S. A., Balkanski, Y. J., Foreman-Fowler, M., Jones, D. B. A., Horowitz, L. W., Fusco, A. C., Brenninkmeijer, C. A. M., Prather, M. J., Wofsy, S. C., and McElroy, M. B.: Three-dimensional climatological distribution of tropospheric $\mathrm{OH}$ : Update and evaluation, J. Geophys. Res., 105, 8931-8980, 2000.

Tanimoto, H., Matsumoto, K., and Uematsu, M.: Ozone-CO correlations in Siberian wildfire plumes observed at Rishiri Island, SOLA, 4, 65-68, doi:10.2151/sola.2008-017, 2008.
Trainer, M., Parrish, D. D., Buhr, M. P., Norton, R. B., Fehsenfeld, F. C., Anlauf, K. G., Bottenheim, J. W., Tang, Y. Z., Wiebe, H. A., Roberts, J. M., Tanner, R. L., Newman, L., Bowersox, V. C., Meagher, J. F., Olszyna, K. J., Rodgers, M. O., Wang, T., Berresheim, H., Demerjian, K. L., and Roychowdhury, U. K.: Correlation of ozone with $\mathrm{NO}_{\mathrm{y}}$ in photochemically aged air, J. Geophys. Res., 98, 2917-2925, 1993.

Val Martin, M., Honrath, R. E., Owen, R. C., Pfister, G., Fialho, P., and Barata, F.: Significant enhancements of nitrogen oxides, black carbon, and ozone in the North Atlantic lower free troposphere resulting from North American boreal wildfires, J. Geophys. Res., 111, D23S60, doi:10.1029/2006JD007530, 2006.

Volz-Thomas, A., Lerner, A., Pätz, H.-W., Schulz, M., McKenna, D. S., Schmitt, S., Madronich, S., and Röth, E. P.: Airborne measurements of the photolysis frequency of $\mathrm{NO}_{2}$, J. Geophys. Res., 101, 18613-18627, 1996.

Wang, T., Carroll, M. A., Albercook, G. M., Owens, K. R., Duderstadt, K. A., Markevitch, A. N., Parrish, D. D., Holloway, J. S., Fehsenfeld, F. C., Forbes, G., and Ogren, J.: Ground-based measurements of $\mathrm{NO}_{\mathrm{x}}$ and total reactive oxidized nitrogen $\left(\mathrm{NO}_{\mathrm{y}}\right)$ at Sable Island, Nova Scotia, during the NARE 1993 summer intensive, J. Geophys. Res., 101, 28991-29004, 1996.

Weinheimer, A. J., Walega, J. G., Ridley, B. A., Gary, B. L., Blake, D. R., Blake, N. J., Rowland, F. S., Sachse, G. W., Anderson, B. E., and Collins, J. E.: Meridional distributions of $\mathrm{NO}_{\mathrm{x}}, \mathrm{NO}_{\mathrm{y}}$, and other species in the lower stratosphere and upper troposphere during AASE II, Geophys. Res. Lett., 21, 2583-2586, 1994.

Wilson, K. L. and Birks, J. W.: Mechanism and elimination of a water vapor interference in the measurement of ozone by UV absorbance, Environmental Science and Technology, 40, 63616367, 2006.

Wisthaler, A., Hansel, A., Dickerson, R. R., and Crutzen, P. J.: Organic trace gas measurements by PTR-MS during INDOEX 1999, J. Geophys. Res., 107, 8024, doi:10.1029/2001JD000576, 2002.

Wofsy, S. C., Sachse, G. W., Gregory, G. L., Blake, D. R., Bradshaw, J. D., Sandholm, S. T., Singh, H. B., Barrick, J. A., Harriss, R. C., Talbot, R. W., Shipham, M. A., Browell, E. V., Jacob, D. J., and Logan, J. A.: Atmospheric chemistry in the Arctic and Subarctic: Influence of natural fires, industrial emissions, and stratospheric inputs, J. Geophys. Res., 97, 16731-16746, 1992.

Wofsy, S. C., Fan, S.-M., Blake, D. R., Bradshaw, J. D., Sandholm, S. T., Singh, H. B., Sachse, G. W., and Harriss, R. C.: Factors influencing atmospheric composition over subarctic North America during summer, J. Geophys. Res., 99, 1887-1897, 1994. 